\title{
Study of Limnological Status of Two Selected Floodplain Wetlands of West Bengal
}

Golam Ziauddin ( $\square$ golamziauddin@gmail.com )

West Bengal University of Animal and Fishery Sciences

\section{Research Article}

Keywords: Floodplain wetland, freshwater, limnological, physicochemical parameters, water quality, fish fauna.

Posted Date: April 22nd, 2021

DOI: https://doi.org/10.21203/rs.3.rs-443104/v1

License: (c) (i) This work is licensed under a Creative Commons Attribution 4.0 International License. Read Full License 


\section{Abstract}

Limnology is the study of all aquatic systems, both lentic and lotic fresh, fresh, and saline including lakes, wetlands, marshes, bogs, ponds, reservoirs, streams, rivers, oceans, etc. about their physical, chemical, and biological characteristics. Among this phytoplankton, Zooplankton, periphyton, benthos are a minute aquatic free-floating microscopic organism, which acts as a larger food source of larval and higher vertebrates and invertebrates including carnivorous and omnivorous fishes. They are related to the growth of juvenile fishes and are also play important role in the transfer of energy from the primary phytoplankton to higher trophic levels. The plankton community fluctuates according to the physicochemical parameters and the relative environment of the water body especially the Rotifers as they are known to change immediately along with the change in water quality .

Realizing the importance of floodplain wetlands and the paucity of literature on the limnology of this ecosystem present investigation was carried out in two floodplain wetlands having characteristics of open (Kole beel, an ox-bow lake formed near Somra Bazar in Hooghly district), and closed beel Suguna beel situated in Nadia District of West Bengal) system during the period 2011-2013.

The physicochemical parameters of the investigated beels' water and soil were, for the most part, favorable for planktonic development. It has an alkaline $\mathrm{pH}$ of 7.5-8.4 and is alkaline. The dissolved oxygen content and Secchi Disc transparency values indicate that the water is in excellent condition. The water was moderately hard, with only trace amounts of nutrients present. Seasonal fluctuations in the water column were apparent, and they were mainly attributable to replenished supplies and volume. The plankton population of the studied ecosystem was made up of a mixed and healthy population of diverse fauna. The greatest diversity was observed during the winter season, when favorable temperature, dissolved oxygen, and other physicochemical parameters of water, as well as optimal solar penetration, coincided. In a closed system (Suguna), the richness of planktonic structure resulted in higher fish production $(1570.05 \mathrm{~kg} / \mathrm{ha} / \mathrm{yr})$ than in an open system (Kole) $(384.4 \mathrm{~kg} / \mathrm{ha} / \mathrm{yr})$. The status of floodplain wetlands was determined to be eutrophic based on various Physico-chemical and biological parameters.

\section{Introduction}

The status of floodplain wetlands is eutrophic, and during the study period, 6 fish species, 14 phytoplankton genera, and 10 zooplankton genera were reported based on different physicochemical and biological parameters. Variation in rainfall, depth of water body, siltation, and other chemical factors are all factors due to year-to-year variations in plankton content in freshwater impoundments (Welch 1952).

Flood plain wetlands have simultaneously been described as the "kidneys of the Flood landscape" and as "biological supermarkets" (Mitsch, 1995a) illustrating the importance of their role in the ecological functioning of most river systems. River regulation in India has resulted in major changes to the flow regime, including changes to the timing and duration of small to medium-sized floods and alteration of the seasonal pattern of flooding. Such changes have altered lateral connections between the river and its 
flood plain and are known to affect plant community structure (Casanova \& Brock, 2000), macroinvertebrate community composition (Quinn et al, 2000) in flood plain wetlands. As the river and its flood plains are inextricably linked, such change to the flood plain wetlands magnifies the effects of flow regulation on the ecological integrity of Australian rivers.

The structure of the floodplain plant community, both emergent and submerged, is an equally important pillar upon which to support sensible management policies. Several important consequential issues are associated with these two principal components. They are inter alia the quality of floodplain water, and the response of the faunal community to changes in the floodplain water, and the response of the faunal community to changes in the floodplain water, as we are aware of the sensitivity of the fauna, both invertebrate and vertebrate, to both insidious and cataclysmic environmental change.

Primary productivity is an important criterion for assessing a water body's productivity. When the nutrient status is low, primary productivity and fish production suffer as well (Singh and Desai 1980), meaning that primary productivity is inversely proportional to the nutrient concentration. Many researchers have studied the primary productivity of water bodies in various locations and at various times of the year, but they have only found one peak of primary production in reservoirs during the summer or early summer (Singh and Desai 1980). Except for the work of Sreenivasan $(1964,1968)$, Ganapati and Sreenivasan (1970), Kaliamurthi (1978), and Natarajan and Pathak (1979), knowledge of primary production in the tropics are still limited (1980). There is almost no detail on the ecological productivity of swamps, oxbow lakes, and other wetlands (Laal 1981 and Yadav 1988). This paper aims to investigate the relationship between primary production and planktonic structure in two eco-systems with open and closed characteristics.

Various limnological studies have been carried out in important wetlands of the state. It is evident from above that the limnology of the small floodplain wetlands has been neglected from a study point of view and no action regarding the proper management of these wetlands has been taken. However, the limnology of this wetland has been the subject of interesting studies.

\section{Materials And Methods}

\section{Brief description of the study area}

Saguna beel is a closed system (S) and the basin is solely dependent on rains for a water source. It is almost rectangular with a water spread area of 40 ha and lie between latitude $88^{\circ} 4^{\prime} \mathrm{E}$ and longitude $22^{\circ}$ $6^{\prime} \mathrm{N}$ and located at Kalyani district Nadia, West Bengal. The bee/ was a defunct watercourse, which earlier had a connection with the river Hooghly.

The Kole beel, an open system, is a shallow saucer-shaped basin of 6-kilometer length having a total area of 81.6 ha. Kole bee/ lies between latitude $88^{\circ} 7^{\prime} \mathrm{E}$ and longitude $23^{\circ} 2^{\prime} \mathrm{N}$ and located at Somra Bazar, district Hooghly, West Bengal. The beel is connected with the river Bhagirathi with the braided channel. 
The climate is tropical, hot, and humid with high fluctuations in temperature. The climate is of tropical monsoon type. Annual rainfall varies between $1600 \mathrm{~mm}$ and $2050 \mathrm{~mm}$. Following APHA (1995) and Jackson, Physico-chemical parameters on soil and water were calculated every month (1973). A certified mercury-filled Celsius thermometer sensitive to $0.1^{\circ} \mathrm{C}$ and a digital pH meter (Hanna instruments, Portugal) were used to measure non-depth water temperature and $\mathrm{pH}$ in situ. $\mathrm{A} 20 \mathrm{~cm}$ diameter black and white Secchi disc were used to calculate Secchi depths once on each sampling day.

All water samples for chemical analysis were taken at approximately the same time of the day (i.e. between 0800 and 0900 IST). Water samples for dissolved oxygen, combined carbon dioxide, dissolved chlorides, and silica were analyzed following the methods outlined by Wetzel \& Likens (1990) and Clesceri et al. (1998). Furthermore, one portion (15-20 ml) of each water sample was filtered through Whatman No. 41 filter paper and the filtrate was used for determining concentrations of the total were collected in a $500 \mathrm{ml}$ wide-mouthed polypropylene bottle for analyzing the Physico-chemical characteristics like temperature, $\mathrm{pH}$, alkalinity, dissolved oxygen, hardness, phosphate, nitrite, nitrate, chloride, sulfate, calcium, salinity, conductivity and total dissolved solids (TDS). Chemical analysis was done in the field and laboratory following the standard methods of APHA (1995).

\section{Descriptive statistics}

PROC MEANS procedure of SAS® (SAS Institute, 2010) was used to estimate the descriptive statistics, viz. minimum, maximum, mean, standard error, and coefficient of variation for all parameters.

\section{Analysis of variance (ANOVA)}

Analysis of variance (ANOVA) was used to discern significant differences among the parameters. PROC GLM procedure of SAS ${ }^{\circledR}$ (SAS Institute, 2010) was used which operates on both balanced and unbalanced designs. A significant source of variations was detected by GLM procedure. Boxplot of parameters was constructed by PROC GLM procedure of SAS $\circledast$ for parameters have shown distribution range of parameters (SAS Institute, 2010).

\section{Result \& Discussion}

\section{Water phase}

\section{Water temperature}

The analysis of variance revealed that there was a month-wise and wetland type-wise significant difference in water temperature (Table- 1). The Kole wetland has shown significantly higher values of water temperature in comparison with Saguna (Figure-1).

\section{Transparency}

The analysis of variance revealed that there was a month-wise and wetland type-wise significant difference in transparency (Table-1). The Saguna wetland has shown significantly higher values of 
transparency in comparison with Kole (Figure- 2a).

\section{Water reaction $(\mathrm{pH})$ :}

The analysis of variance revealed that there was a month-wise and wetland type-wise significant difference in $\mathrm{pH}$ (Table-1). The Saguna wetland has shown significantly higher values of Specific conductivity in comparison with Kole (Figure-2b).

\section{Total alkalinity}

The analysis of variance revealed that there was a month-wise and wetland type-wise significant difference in Total alkalinity (Table-1). The Kole wetland has shown significantly higher values of Total alkalinity in comparison with Saguna (Figure- 3a).

\section{Total hardness:}

The analysis of variance revealed that there was a month-wise and wetland type-wise significant difference in Total hardness (Table-1). The Kole wetland has shown significantly higher values of Total hardness in comparison with Saguna (Figure-3b).

\section{Specific conductivity}

The analysis of variance revealed that there was a month-wise and wetland type-wise significant difference in Specific conductivity (Table-1). The Kole wetland has shown significantly higher values of Specific conductivity in comparison with Saguna (Figure - 4a).

\section{Dissolved oxygen:}

The analysis of variance revealed that there was a month-wise and wetland type-wise significant difference in Dissolved oxygen (Table-1). The Kole wetland has shown significantly higher values of Dissolved oxygen in comparison with Saguna (Figure - 4b).

\section{Nitrate-Nitrogen}

The analysis of variance revealed that there was a month-wise and wetland type-wise significant difference in Nitrate (Table-1). The Kole wetland has shown significantly higher values of Nitrate in comparison with Saguna (Figure- 5a).

\section{Phosphate-phosphorus:}

The analysis of variance revealed that there was a month-wise and wetland type-wise significant difference in phosphorus (Table-1). The Kole wetland has shown significantly higher values of phosphorus in comparison with Saguna (Figure-5b).

\section{Silicate-silica}

The analysis of variance revealed that there was a month-wise and wetland type-wise significant difference in silica (Table-1). The Kole wetland has shown significantly higher values of silica in 
comparison with Saguna (Figure-6a).

\section{Soil quality}

\section{Soil pH}

The analysis of variance revealed that there was a month-wise and wetland type-wise significant difference in soil pH (Table-1). The Saguna wetland has shown significantly higher values of soil pH in comparison with Kole (Figure-6b).

\section{Organic carbon}

The analysis of variance revealed that there was a month-wise and wetland type-wise significant difference in soil organic carbon (Table- 1). The Saguna wetland has shown significantly higher values of soil organic carbon in comparison with Kole (Figure-7a).

\section{Available nitrogen}

The analysis of variance revealed that there was a month-wise and wetland type-wise significant difference in soil available nitrogen (Table-1). The Kole wetland has shown significantly higher values of soil available nitrogen in comparison with Saguna (Figure - 7b).

\section{Available phosphorus}

The analysis of variance revealed that there was a month-wise and wetland type-wise significant difference in soil available phosphorus (Table-1). The Saguna wetland has shown significantly higher values of soil available phosphorus in comparison with Kole (Figure-8a).

\section{BIOTIC COMMUNITIES}

\section{Plankton}

\section{Phytoplankton}

\section{Myxophyceae}

The analysis of variance revealed that there was a month-wise and wetland type-wise significant difference in phytoplankton (Table-1). The Saguna wetland has shown significantly higher values of Myxophyceae in comparison with Kole (Figure- 8b).

\section{Chlorophyceae}

The analysis of variance revealed that there was a month-wise and wetland type-wise significant difference in Chlorophyceae (Table-1). The Saguna wetland has shown significantly higher values of Chlorophyceae in comparison with Kole (Figure- 9a). 


\section{Bacillariophyceae}

The analysis of variance revealed that there was a month-wise and wetland type-wise significant difference in Bacillariophyceae (Table-1). The Saguna wetland has shown significantly higher values of Bacillariophyceae in comparison with Kole (Figure- 9b).

\section{Euglenoida}

The analysis of variance revealed that there was a month-wise and wetland type-wise significant difference in Euglenoida (Table-1). The Saguna wetland has shown significantly higher values of Euglenoida in comparison with Kole (Figure - 10a).

\section{Dinophyceae}

The analysis of variance revealed that there was a month-wise and wetland type-wise significant difference in Dinophyceae (Table-1). The Kole wetland has shown significantly higher values of Dinophyceae in comparison with Saguna (Figure-10b).

\section{Xanthophyceae}

The analysis of variance revealed that there was a month-wise and wetland type-wise significant difference in Xanthophyceae (Table- 1). The Saguna wetland has shown significantly higher values of Xanthophyceae in comparison with Kole (Figure-11a).

\section{Zooplankton}

\section{Copepod}

The analysis of variance revealed that there was a month-wise and wetland type-wise significant difference in Copepods (Table-1). The Saguna wetland has shown significantly higher values of Copepods in comparison with Kole.

\section{Rotifer}

The analysis of variance revealed that there was a month-wise and wetland type-wise significant difference in Rotifers (Table-1). The Saguna wetland has shown significantly higher values of Rotifers in comparison with Kole.

\section{Cladocera}

The analysis of variance revealed that there was a month-wise and wetland type-wise significant difference in Cladocera (Table-1). The Saguna wetland has shown significantly higher values of Cladocera in comparison with Kole).

\section{Benthic Macroinvertibrates}


The occurrence of benthic organisms sharply declined from the late winter season reaching the lowest values during the monsoon. The general trend of abundance in the studied lakes followed a sequence of Gastropod > Oligochaete > Chironomids > Bivalves > others.

\section{Gastropod}

The analysis of variance revealed that there was a month-wise and wetland type-wise significant difference in Gastropod (Table-1). The Kole wetland has shown significantly higher values of Gastropod in comparison with Saguna.

\section{Bivalve}

The analysis of variance revealed that there was a month-wise and wetland type-wise significant difference in Bivalve (Table-1). The Kole wetland has shown significantly higher values of Bivalve in comparison with Saguna.

\section{Oligochaete}

The analysis of variance revealed that there was a month-wise and wetland type-wise significant difference in Oligochaete (Table-1). The Kole wetland has shown significantly higher values of Oligochaete in comparison with Saguna.

\section{Chironomids}

The analysis of variance revealed that there was a month-wise and wetland type-wise significant difference in Chironomids (Table-1). The Kole wetland has shown significantly higher values of Chironomids in comparison with Saguna.

\section{Discussion}

\section{WATER QUALITY CHARACTERISTICS}

\section{Physical Attributes}

\section{Transparency}

In the present study, the two selected beels were found to have low transparency during the summer period (particularly May- June), which is attributed to the wind action and phytoplankton bloom. Various workers have also reported similar seasonal fluctuations in lake water transparency (Michael, 1969; Kumar, 1985).

\section{Temperature}

Kumar (1985) calculated stratified temperature in a beels eco-system in West Bengal's Nadia district. The water temperature closely matched the temperature of the atmosphere in the beel habitats studied 
(Tables - 1). Variation in water temperature was quite distinct during different seasons throughout the study. According to Bhowmik (1988), maximum and minimum temperatures in West Bengal beels and baors ranged from 17.5 to $32.0 \mathrm{OC}$, which is consistent with the current research. Rai and Dutta Munshi (1989) have also reported that the presence of macrophytes profoundly influences water temperature. The present study also confirms the same. According to Banerjea (1967); Jhingran (1989) in water bodies with high organic contents in bottom mud, large-scale mortality takes place in summer months especially after a shower or cold wind.

\section{CHEMICAL ATTRIBUTES}

\section{Dissolved oxygen}

The prime life-bearing gas in aquatic media was within the moderate range of 6.4 to $10.8 \mathrm{ppm}$ (Table- 1 ). The reason for the maximum stratification of oxygen in monsoon may be attributed to the high rate of surface mixing of atmospheric oxygen due to the showering of a raindrop (Banerjea, 1967). It is interesting to mention that the higher concentration of oxygen in the surface water during monsoon was always not in confirmation with the high plankton density whereas Das and Srivastava, (1956) reported that the phytoplankton peak corresponds to the high oxygen values while zooplankton peaks are associated with low oxygen values. Oxygen content observed to be poor during the period of the high temperature such as the summer season (Bhowmik, 1968; 1988; Sugunan et al., 2000) conforms with the present study. Kumar (1985) also reported similar observations. Dense aquatic vegetation, shallow water depth, and intense fishing activities can cause large fluctuations in the dissolved oxygen content of water in the beels. (Yadava et al., 1987).

\section{Water reaction $\mathrm{pH}$}

In the present investigation, the hydrogen-ion concentration in the surface water of the beels was 8.0 and above excepting on few occasions. The observed $\mathrm{pH}$ as 8.0 and above has been recorded to be productive by various workers (Hutchinson, 1957; Banerjea, 1967). Michael (1969) observed that when pH ranged between 7.3 and 8.4 the water provided optimum conditions for the growth of plankton. The present study bears the agreement of alkaline $\mathrm{pH}$ with the study of Bhowmik (1988) where the $\mathrm{pH}$ value of the beels and baors of West Bengal was recorded between 6.8 and 9.1.

\section{Alkalinity}

Since total alkalinity values are the resultant of the entire biological and chemical process taking place in the water body, as such it is also taken as a rough index of productivity of the water body (Laal, 1981). In the present investigation, the alkalinity of the beels waters was observed to be within the product range. The high alkalinity value was recorded in beels infested with a high density of macrophyte-associated fauna and benthic biomass. Sugunan et al., (2000) reported similar observations.

\section{Free $\mathrm{CO}_{2}$}


Such absence of free $\mathrm{CO}_{2}$ in water was found to be related to the presence of heavy phytoplankton populations (Michael, 1969). The pronounce absence of the free $\mathrm{CO}_{2}$ at the subsurface level of the water was in confirmation of the observation made by Reid (1961), who reported that at pH 8 and above the free $\mathrm{CO}_{2}$ is usually absent. Most fish species will survive waters containing up to 60 ppm (Hart, 1944).

\section{Specific conductivity}

The specific conductance of water is a measure of the resistance of a solution to electrical flow, which declines with increasing ion content (Wetzel, 2001). The specific conductivity values recorded from these lakes were in an acceptable range. It has been reported an optimum range as $250-400 \mu \mathrm{S} / \mathrm{cm}$ and opined that specific conductivity above $400 \mu \mathrm{S} / \mathrm{cm}$ does not limit or favor productivity. The total concentration of solid constituents in natural waters is measured by specific conductivity.

\section{Nitrate-Nitrogen}

In the present investigation, the values of water-soluble nitrate varied from system to system and with seasonal changes. The level of the nutrient was $0.3-1.5 \mathrm{ppm}$ in Kole, while, it was comparatively higher in the range of 0.8 to $1.3 \mathrm{ppm}$ in Saguna (Tables - 1). The fluctuation trend in nitrate level indicated mesotrophic to the eutrophic condition of the beels (Goldman and Horne, 1983). The nitrate levels in the studied beels were within the productive range (Banerjea, 1967) and ideal for plankton growth, which is consistent with the findings of the study.

\section{Phosphate-phosphorus}

The phosphate cycle of the beels was in correlation with the dissolved oxygen and is known to play important role in controlling the rate of phosphorus release from the sediment to the photic zone (Munawar, 1970). A major distinguishing factor among the water bodies is the difference in frequency and length of river inputs or connectivity (Hamilton and Lewis, 1990; Amoros, 1991). The nutrient enrichment during low water was attributed by Hamilton and Lewis (1987) to turbulence from wind action and sediment resuspension. It was attributed by Boneto et al. (1984) to hypolimnetic anoxic conditions and the release of nutrients from the sediment.

\section{Silicate}

Many workers (Bhowmick, 1968) have observed a direct relationship between silicate content and diatom population in the water body. Furch (1984) found a similar phenomenon in Amazonian 'Varzea' (flood plain) lakes and a floodplain lake in Sao Paulo, Brazil.

During the study period, water temperature, $\mathrm{pH}$, Dissolved Oxygen (DO), Free Carbon Dioxide $\left(\mathrm{FCO}_{2}\right)$, Total Alkalinity were measured monthly for six months. The limnological parameters of the study site were found to be highest during October 2012. the $\mathrm{pH}$ of the Kole was found to be at par during the six months study period. DO and FCO2 were found to be highest during October and lowest during the winter months i.e, December 2011 - January 2013. 
The water quality, nutrient level, and fish fauna of the Kole beel show change from time to time as it receives different types of water at the different parts of the year. During monsoon, the water from river Ganga enters the beel along with nutrients, fishes, and inundates the beel. Again the combined flow from the rivulet upstream along with nutrient and water from the catchment area reverts the flow to the Ganges that continues till the flood receded. Therefore, in both cases, many fishes enter the beel along with and against the water current giving a dual benefit to the beel.

\section{SEDIMENT CHARACTERISTICS \\ Chemical attributes \\ Soil pH}

In the present study, the $\mathrm{pH}$ values recorded in the soil (6.0-7.0) were thus indicative of high productivity in the investigated beels, which confirms the study. Das (2000) working on the bee/s of West Bengal has reported a similar $\mathrm{pH}$ of soil.

\section{Organic carbon}

The fluctuation of organic carbon in an aquatic system with the change of places and during different seasons has been reported by various workers (Bhowmick, 1968). The seasonal fluctuation indicated a definite pattern of peaks of organic carbon as observed by Bhowmick (1968). Kumar (1985) reported a similar observation where organic carbon values ranged from 3.8 to $4.8 \%$ in beels located at Kalyani.

\section{Available nitrogen}

In the present study, available nitrogen in the beels sediment was varying in concentrations. The nitrate and available phosphorus are considered to be limiting factors, being the primary nutrient for ecosystem functions (Carney et al., 1993 and Brown, 1981). The nitrogen levels in beels were within the range of favorable productivity (Banerjea, 1967).

\section{Available phosphorus}

It is well documented that in shallow lakes, aquatic macrophytes act as a sink for nutrients, both nitrate $(\mathrm{N})$ and Phosphorus $(\mathrm{P})$, during their growth phase withdrawing up to $60 \%$ of $\mathrm{N} \& \mathrm{P}$ from the sediment and after their decomposition releases them back to the water as well as to the sediment (Donk et al., 1993). According to Sugunan et al., (2000), usable phosphorus values were lowest in closed and weedchoked beels (traces to $3.18 \mathrm{mg} / 100 \mathrm{~g}$ of soil), higher in closed but moderately weed-infested beels (traces to $7.6 \mathrm{mg} / 100 \mathrm{~g}$ of soil), and maximum in open beels (traces to $10.08 \mathrm{mg} / 100 \mathrm{~g}$ of soil), in comparison to other nutrient parameters. This observation is based on the study made on a large number of beels of West Bengal and eventually, the present observation is, by and large, in agreement with the findings and indicative of productive.

\section{Biotic Communities}




\section{Planktonic structure}

The plankton population in the bee/s systems was diverse in respect of species and population density. From the 2 systems, 62 species of plankters belonging to 51 genera and 29 families were identified. (Table-1). Sugunan et al., (2000) found that phyto and zooplankton populations in West Bengal flood plain wetlands were lower during the southwest monsoon, but increased after the ecosystem stabilized and the plankton population formed using inorganic nutrients and organic matter brought in by the incoming flood or run-off water. Bhowmik (1988) also found that phytoplankton dominated the maximum plankton population in the summer, while zooplankton dominated in the winter. In Bihar, Jha (1997) discovered a higher plankton population in closed flood plain lakes.

The beer's phytoplankton was low due to the use of nutrients by a thick growth of macro vegetation. (Yadava et al., 1987). The wetlands exhibited strong competition between the macrophytes and phytoplankton in respect to sunlight and nutrients $(\mathrm{N}: \mathrm{P})$, influencing the abundance and quality of phytoplankton from one system to another (Wetzel, 2001). Macrophytes being the dominant autotrophs might have used the available nutrients, sunlight more efficiently, as such grow rapidly, almost shadowing the proliferation of phytoplankton (Boyd, 1971).

Several researchers have documented increased phytoplankton production when dissolved oxygen levels are higher. (Alikunhi et al., 1955; Das and Srivastava, 1956; Moitra and Bhattacharjee, 1965; Saha et al., 1971). However, no such connection could be made during the ongoing investigation. According to Reid (1961), as the temperature is lowered, the solubility of oxygen in water increases.

Cairns (1965) investigated the optimum temperature range $\left(15-30^{\circ} \mathrm{C}\right)$ as the most favorable for the growth of diatoms. Copepods were present throughout the year, but there was no discernible trend. Rotifers have a diverse ability to survive in a variety of habitats, as some feed on phytoplanktons, others on detritus and bacteria, and still others have been identified as predatory raptors (Singh, 2000). Rotifers predominate in Indian freshwaters, which is a natural occurrence. (Michael, 1969; Lahon, 1983). Singh (2000) recorded maximum production of rotifers during the summer season. Similar observations have been made by Michael (1966) and Singh (2000). Their growth seemed to be favored by a temperature range of 23.5 to $26.1^{\circ} \mathrm{C}$, which is within the optimal temperature range for protozoan growth (Pennak, 1953).

During the investigation, a total of 15 taxa from three classes were discovered: 5 Cladocera taxa, 4 Copepoda taxa, and 6 Rotifera taxa. The site's highest Zooplankton abundance was in October 2012, and the lowest was in February 2013. A similar study in three different kinds of freshwater waterbodies in Penang Island, Ismail, and Zaidin, 2015 reported the highest Zooplankton abundance in November while the lowest in February. Among all the Zooplankton groups, Rotifera was reported to be dominant among other groups during the period of investigation consisting of 6 taxa of which Filinia sp. shows highest abundance and Keratella sp. shows the lowest abundance throughout the six months study. In the Cladocera group, Moina sp. shows highest and Bosmina sp. shows the lowest abundance while 
Copepoda group, Mesocyclops sp. shows highest abundance and Microcyclops sp. shows the lowest abundance throughout the study period. Compared to all other taxa, Filinia sp. of the Rotifera group were found to dominate the population of Zooplankton. The abundance of the Rotifera group may indicate the presence of dissolved solids in the study site, as they are known to increase the growth of minor phylum of Zooplankton in the water body (Goswami and Mankodi, 2012).

Figures show the percentage composition of Zooplankton in the study during the period of investigation. Cladocera contributes the highest percentage of $43 \%$ of the total Zooplankton composition followed by $42 \%$ of Rotifera and $15 \%$ of Copepoda. The presence of the highest percentage of Cladocera again depicts the better condition of the water body and can be used for the aquacultural program. Cladocera shows the highest abundance among other groups of Zooplankton present in the study site. Cladocera was found to be abundant during October 2012 whereas Copepoda and Rotifera were also found abundantly during October 2012. The lowest abundance of Zooplankton composition was found to be during February 2013.

\section{Limnology and plankton community of floodplain wetlands}

Floodplain lakes' chemistry and biology are strongly affected by their proximity to rivers. (Amoros and Roux, 1988; Van den Brink et al., 1992; Tockner et al., 2000b). One of the most striking features of plankton populations is the ongoing substitution of organisms (Hutchinson, 1967; Edmondson and Litt, 1982). The stagnant floodplain waters are one-of-a-kind environments in terms of water chemistry, phytoplankton and zooplankton composition, and dynamics, with exceptional spatial and temporal heterogeneity in the ecosystem, resulting in high species and population richness (Pethart, 1995). Changes in the prevailing environment over the wetland, as well as external factors, may cause changes in the physicochemical parameters (Abbasi, 1997). The phyto- and zooplankton community composition in floodplain lakes are influenced by hydrology, relevant nutritional resources, and habitat characteristics, primarily through $\mathrm{N}$ and $\mathrm{P}$ input from eutrophic main channels during floods. The complexity of ecosystems created by the presence of aquatic plants was linked to plankton species richness (Van den Brink et al., 1994). Plankton diversity in semi-isolated floodplain reservoirs, as well as natural riverfloodplain systems, are known as biodiversity hotspots (Ward et al., 1999), due to the variability in hydrology and disturbances of the lentic, lotic and semi-aquatic habitat types present. When connectivity is considered the most important disruption of floodplain lakes, lakes with intermediate connectivity have the most diversity, while lakes that are permanently linked (highest connectivity) and isolated (lowest connectivity) have the least diversity. (Roozen, 2005).

The highest phytoplanktonic population is observed during the rising water cycle when limnological changes are most visible as river water reaches the floodplain for the first time. Water and plankton populations from the pools and depressions are replaced by the flood. Nitrate-nitrogen is abundant in river water, which can be used as a source of nutrients and oxygen. Diatoms and green flagellates, Volvocales, are carried in by the flood, and they will spread and take over after the flood. (Pethart, 1995). The river is a highly complex entity that has a significant impact on the limnology of stagnant waters in the floodplain. Even though plankton cannot swim against currents, rivers also have an abundance of it. 
(Hynes, 1970; Winner, 1975; Rzoska, 1978). Factors influencing the transport of species from the source region to the water, and factors affecting the growth and reproduction of organisms in the river, are the two types of factors that influence the abundance of plankton in rivers. (Hynes, 1970). Plankton can be supplied to the river by standing water in contact with the channel.

Many tropical rivers have a wide stretch of the natural floodplain that could be significant zooplankton sources (Saunders and William, 1988). Inundation of source areas is caused by changes in water levels, which increases zooplankton abundance.

The timing of a flood is thought to be important in assessing the effects on the water quality of flooded lakes. (Junk et al., 1989; Bayley, 1991; Hein et al., 1999; Tockner et al., 2000b). Phytoplankton is extremely sensitive to environmental changes, and major shifts in phytoplankton species composition are often a result of substantial changes in ecosystem ambient conditions. (Devassy and Goes, 1988, 1989). Floodplain lakes with a long annual flood cycle have cyanobacteria, Chlorophyta, and filter-feeding zooplankton taxa associated with open water. Bacillariophyceae and scraping zooplankton taxa associated with aquatic macrophytes, on the other hand, are popular in floodplain lakes with short annual flood durations. (Van den Brink et al., 1994). Physical properties of water, such as mixing and light availability, are two of the most important determinants of phytoplankton vertical distribution. (Reynolds, 1994). These properties are closely related to seasonal flood pulse changes in floodplain lakes. (Junk et al., 1989). Sept and Reynolds (1995) discovered that a water level's phytoplanktonic production was affected by temperature, light, and nutrients. Lentic phytoplankton is washed away during the inundation, while riverine species are taken in by floodwaters. Nonetheless, river water causes phytoplankton dilution and wash-out, resulting in a drop in abundance (Talling, 1986). Under insecure environmental conditions, small flagellate forms (cryptophytes or green algae) with rapid growth rates (r-selected) often dominate. (river water inflow can be considered a disturbance factor) (Reynolds, 1984). Another significant aspect is diatom input into river water, where they are often dominant. (Moss et al., 1989; Kasten, 2003). Zooplankton is an integral component of the marine ecosystem, performing a broad range of important functions. Water is purified by feeding on phytoplankton and microorganisms. The quality of water can be assessed based on the species dominance in the zooplankton population. The clay content of floodplain soils is higher than that of depressional wetland soils. (C.B. Craft, unpublished data). According to the few studies that have been conducted, open (floodplain) and closed (depressional) wetlands both sequester similar quantities of organic $\mathrm{C}$ and $\mathrm{N}$.

The relatively high rate of soil organic $\mathrm{C}$ and $\mathrm{N}$ deposition in floodplain soils and possibly other floodplain wetlands is due to slower soil accretion and higher $\mathrm{C}$ and $\mathrm{N}$ concentrations in the subsoil. As demonstrated by higher $\mathrm{P}$ accumulation in floodplain wetlands, catchment size and connectivity to sources of fine-textured (clay) sediments influence P retention (Christopher and William, 2000). Wetland productivity, species diversity, and water quality are all influenced by nutrient accumulation and storage.

External nutrient loadings and accumulation are often linked to high primary and secondary productivity (Brinson et al., 1981; Hopkinson et al., 1992). The potential of freshwater wetlands to remediate water 
quality depletion by collecting sediment and sequestering nutrients is one of their advantages $(\mathrm{C}, \mathrm{N}$, and $\mathrm{P})$. However, the efficacy of wetlands in nutrient and sediment retention is based on several factors, including the scale of the watershed, the land use within it, and the degree of wetland access to open water habitats. (Christopher and William, 2000). In infertile wetlands that receive little in the way of fertilizer subsidies or have low soil nutrient supplies, species diversity and the prevalence of rare species are typically higher. (Moore et al., 1989; Marrs, 1993). Long-term lake studies have provided clear evidence of the impact of increased major nutrients (nitrogen and phosphorus) on lake production and biota variations. (Abd El-Karim, 2009).

\section{Macrophyte}

Living organisms and their abiotic surroundings are inextricably linked and interact with one another (Odum, 1983). Aquatic plants play an important role in the habitats of lakes, wetlands, rivers, and streams all over the world (Jamil, 1993). Sharma (1995) also recorded dominance by submerged and emergent vegetation in Kawar lake of Bihar. The high turbulence of water was perhaps the main constraint for lesser growth of macrophytes in Kole which conforms with the study of Saha et al. (1971); Sugunan et al., (2000). Submerged macrophytes regulate plankton density and primary productivity by providing optimal light quality and quantity, temperature, and total alkalinity (Yadava, 1987). Kole beel had a lower infestation and biomass of macrophytes than the parent river, which was partly due to management action and partly due to contact with the parent river.

The results show that both free-floating and submerged macrophytes have a wide seasonal variation in biomass. Camargo and Florentino (2000) found that the biomass of aquatic macrophytes in tropical water bodies varies greatly from season to season. Junk (1986), Junk and Piedade (1993), Da Silva and Esteves (1993), and Camargo and Esteves (1993) all made similar observations (1996). Saha et al. (1990) found a significant difference in water quality parameters during the planktonic and macrophytic phases in Kulia beels (closed beels) in West Bengal. During the macrophyte process, they discovered a lot of Secchi disc visibility (from top to bottom). In the current analysis, however, no direct correlation between macrophytic dominance and transparency could be found.

Munawar (1970) claimed that a dense macrophyte population would result in increased photosynthetic activity and, as a result, an increase in $\mathrm{pH}$. The absorption of phosphorus by macrophytes both from the water and sediment is well known (Bristow, 1975; Denny, 1995; Chamber et al., 1989 and Gunnison and Barko, 1989). This suggests that nitrate is a more limiting nutrient for macrophyte growth in these lakes than phosphorus.

Aquatic macrophytes play an important role in the dynamics of the Beels' physicochemical and biological properties. Aquatic macrophytes provide nutrition to herbivores while also strengthening the Beel ecosystem's detritus food chain.

Marginal plants, especially Ipomoea fistulosa, were found in the Closed Beel. In the closed Beel, other aquatic plants such as Jussiaeadiffusa, Alternantheraphylloxeroides, and Paspalum scrobiculate were 
not present. Floating pants Eichhornia crassipes (Panimeteka) and Monochoria vaginalis (bhatmeteka) are the most common macrophytes, followed by Chara (submerged).

The open beel was devoid of floating plants such as Trapa natans var. bispinosa (cattail). Ipomoea fistulosa, Ipomoea aquatica (waterspinach), Ipomoea carnea, Alternantherasessilis, Alternantheraphylloxeroides, Jussicadiffusa, and Paspalumscorbiculatum are examples of marginal amphibious plants that can thrive on damp soil lands as well as float on the water surface. Monochoria vaginalis (water hyacinth), Eichhornia crassipes followed by Chara (submerged), and Ipomoea fistulosa (marginal) are all dominant macrophytes in the Open beel. Aquatic weeds are heavily infested in West Bengal's Beels. Eichhornia crassipes and Monochoria vaginalis (water hyacinths), Chara (submerged), Salvina, Lemna, Wolffia, Potamogeton, Hydrilla verticillate, vallisnereia, Ipomoea fistulosa, Nymphaea cristata (water lily), Eurylferox (Makhna), etc. are some of the common forms.

The primary productivity of the studied beels came from two sources: phytoplankton and macrophytes. The rate of energy transformation by phytoplankton is lower than that of macrophytes, according to Beels. It's a complicated process to transfer energy from the primary producer to fish (carnivores). The fish reflect a fraction of the energy trapped by primary producers as a secondary product of the beels. It's a complicated process to transfer energy from the primary producer to fish (carnivores). The fish reflect a fraction of the energy trapped by primary producers as a secondary product of the beels. In the Open Beel, the average Gross primary output (GPP) by phytoplankton is $1.82 \mathrm{~g} / \mathrm{m} 2$ per day. The value is $1.68 \mathrm{~g} / \mathrm{m} 2$ /day in the case of Closed Beel. The phytoplankton of Open Beel produced more gross primary production (GPP) than that of Closed Beel. The Open Beel's Net Primary Production (NPP) is $1 \mathrm{~g} / \mathrm{m} 2$ per day, while the Closed Beel's NPP is $0.83 \mathrm{~g} / \mathrm{m} 2$ per day. In the Beels, differences in phytoplankton net primary production (NPP) are $0.17 \mathrm{~g} / \mathrm{m} 2 /$ day.

Ranges of Gross Primary Production (GPP) $1206-4371 \mathrm{~g} / \mathrm{m} 2 / \mathrm{yr}$. and $506 \mathrm{~g} / \mathrm{m} 2 / \mathrm{yr}$. with an average value of $2655.80 \mathrm{~g} / \mathrm{m} 2 / \mathrm{yr}$ and $2142.27 \mathrm{~g} / \mathrm{m} 2 / \mathrm{yr}$ in the Closed and Open Beels respectively. Lowest Gross Primary Productive (GPP) was observed in December $(1456 \mathrm{~g} / \mathrm{m} 2 / \mathrm{yr}$.) in the Open Beel and $2160.33 \mathrm{~g} / \mathrm{m} 2$ /yr in the Closed Beel. In Closed Beel, the highest average value was observed in November $(3174.33 \mathrm{~g} / \mathrm{m} 2 / \mathrm{yr})$ and in November $(3174.33 \mathrm{~g} / \mathrm{m} 2 / \mathrm{yr})$. GPP falls during the winter and steadily rises during the summer. If water is accessible in the wetlands, Eichhorniacrassipes and Monochoria vaginalis (water hyacinth) are usually abundant throughout the year. Rainfall, high and high-temperature humidity all influence their development. During the monsoon and post-monsoon, the dominant period was observed.

Despite the drying up of some patches of the wetland beds, some weeds, such as Hydrilla verticillata, Vallisneria spiralis, and Potamageton octundrus, renew their seasonal cycle. Over the winter season, the macrophytes decompose. The availability of water in the wetlands' bed influences the seasonal variation of biomass.

Despite their immense ability, the Beels only use around $1 \%$ of the energy used by fish, and the rest is transformed into a detritus food chain at the bottom of the beels. Because of the two types of 
productivity sources, the primary productivity of the Beels is higher than the productivity of any other freshwater reservoir. Most of these macrophytes are not specifically grazed by herbivores, and the unused material is deposited at the bottom as detritus energy, which is generally high in both Beels. Detritus levels in the Open Beel ranged from 0.91 to $4.56 \mathrm{~kg} / \mathrm{m} 2 / \mathrm{yr} / \mathrm{m} 2$, with an average of $2.55 \mathrm{~kg} / \mathrm{m} 2 / \mathrm{yr}$. Detritus levels in Closed Beel ranged from 2.05 to $4.75 \mathrm{~kg} / \mathrm{m} 2 / \mathrm{yr}$, with an average of $2.75 \mathrm{~kg} / \mathrm{m} 2 / \mathrm{yr}$. In both the Beels, the value of detritus was higher in the winter season $(4.45 \mathrm{~kg} / \mathrm{m} 2 / \mathrm{yr}$.) than in the summer season $(1.3 \mathrm{~kg} / \mathrm{m} 2 / \mathrm{yr}$.). The rich growth of marginal and submerged vegetation in the Brahmaputra floodplain wetlands is a unique feature due to heavy nutrient loading from both allochthonous and autochthonous sources. These macrophytes often supplant the plankton population, hastening eutrophication by replacing the plankton community with macrophytes as the primary producer. This results in a higher rate of evapotranspiration and lake amplification. This method, however, can be reversed with good management. Open Beels, which have fewer macrophytes (on average 2142.27 $\mathrm{g} / \mathrm{m} 2 / \mathrm{yr}$ ), are best suited for energy transformation by phytoplankton.

The productivity of West Bengal's Closed Beels (average $2655.80 \mathrm{~g} / \mathrm{m} 2 / \mathrm{yr}$ ) is hampered by floating (water hyacinth), submerged (Najas, Vallisnaria, Hydrilla, and Chara), and marginal (Typha) vegetation. As a result, both the Closed Beel $(0.83 \mathrm{~g} / \mathrm{m} 2 /$ day $)$ and the Open Beel $(1 \mathrm{gc} / \mathrm{m} 2 /$ day $)$ have poor net productivity rates.

\section{Macrobenthic community}

Sugunan et al. (2000) opined that the beels of West Bengal support rich growth of benthos, the average density ranging from 90 to 13,238 nos. $/ \mathrm{m}^{2}$. Parameswaran and Vass (1995) stated benthos of the beels of West Bengal is generally dominated by mollusks, insect larvae, nymphs, and Oligochaetes which agrees with the present investigation.

\section{Conclusion}

The limnology and productivity of the two beels are different. Kole and Suguna beels are both shallow and have similar thermal characteristics. Kole beel primary production was poor, ranging from 0.273 to $0.702 \mathrm{~g} \mathrm{C} \mathrm{m-2} \mathrm{day-l.}$

Rain showers in the forenoon resulted in higher development. This confirms Vcrduin's (1957) hypothesis that phytoplankton exposed to low light during the day can still photosynthesize at high rates in the late afternoon when showers occur earlier in the day. Low photosynthetic concentrations are indicated by alkalinities below 50 ppm (Pleasant, Rand, and Namcrov 1962). The comparison between Ooty Lake and Kodaikanal Lake is striking. Probiotics are recommended for water with a lower tropical temperature. Performance was strong in water with a lower tropical temperature, reaching $8.16 \mathrm{~g} \mathrm{C} \mathrm{m}-2$ per day. The lake had been highly active, as shown by improvements in oxygen and alkalinity, except in April 1963, when primary production was poor due to persistent cloudy weather. Output was higher when rain showers occurred, according to the carbon dioxide change process. 
It can be inferred that the nutrients in water and soil in an aquatic environment play a significant role in aquatic production under various temperature regimes. The productivity of relatively regulated water bodies, such as the Suguna beel (closed), is primarily determined by allochthonous nutrient input and management practices. The sources of nutrients in natural open water bodies like the Kole beel, on the other hand, are both allochthonous and autochthonous. Apart from other hydrobiological parameters, the productivity of natural water bodies is affected by several factors such as aquatic vegetation, eutrophication, pollution, and various anthropogenic activities. The abundance of nitrogen and phosphorus in water and soil has a positive association with productivity. However, there was no connection between potassium content and productivity. In contrast to nitrogen and phosphorus, potassium tends to play a smaller role in aquatic production.

In conclusion, phosphorus was released because of repeated drying and wetting. This effect was greater when the drying time was 200 hours rather than 100 hours, suggesting that the degree of drying is a key factor in regulating phosphorus after rewetting.

It is also recognized by the study that human activity remains one of the major ecological elements in the floodplain wetlands and its catchments in both the cases of open and closed floodplain wetlands.

The presence of a good abundance of Cladocera is very much appreciable as they are known to be the staple food of larvae of various culturable fishes. But the increasing abundance of Rotifera may be an indication of the increase of pollutants to the water body.

Just like the other wetlands of the state the Kole Beel experience the most dramatic changes in their trophic status and biota. There is a gradual shrinkage in the size of the wetland due to encroachment, agricultural activities, and human settlement within the wetland causing an imbalance in the wetland ecosystem.

Although the Millennium Ecosystem Assessment estimates that wetlands cover seven percent of the earth's surface and deliver $45 \%$ of the world's natural productivity and ecosystem services.

The existence of these unique resources in this region of the country is under threat due to differential developmental activities and population pressure. This calls for a long-term

planning for the preservation and conservation of these resources.

The water quality of Kole Beel is deteriorating as years are passing by resulting in prolific weed growth, thereby, affecting sustainable food production and potable water for humans and livestock. A large number of people residing in or on the fringe areas of wetlands are partially or entirely dependent upon the aquatic resources of the Beel. The Beel is a habitat of diverse groups of organisms and harbors a vast array of aquatic resources. Therefore, restoration of the Beel is

very much important for maintaining bio-diversity. 
Fish is an important component in people's diets, providing about 2.9 billion people with almost 20 percent of their average intake of animal protein. Fishery sectors are particularly important in developing countries, for providing both food and livelihoods. The Beel offers immense potential for increasing fish production, employment generation, and several other additional sources of income for the rural population of this area of West Bengal.

Therefore, if we can attract the attention of all the regulating bodies for better scientific management and maintenance along with the introduction of culture-based fishery then the fish

production of the beel can be increased 3 fold i.e. up to 668 tonnes of fishes per year.

It is our considered opinion that the fish production of the beel can be augmented if the beel is taken under culture-based fishery using proper scientific management framework. This will require support from the Government especially in i. regulating the flow of floodwater from river Ganges, ii. leasing the beel to the co-operative society with traditional (Koiborta, Mahimal) and trained fisher, iii. strict enforcement of regulations (Indian Fisheries Act, 1897) regarding fishing

access, period, time, type, mesh size, gears, encroachment, and free riders, iv. training the fisher about the recent scientific technique. 
Table 1

Descriptive statistics of Water quality parameters data of Saguna

\begin{tabular}{|llll|}
\hline Parameters & Mean & SE & SD \\
\hline Transparency $(\mathrm{m})$ & 1.9 & 0.06 & 0.27 \\
\hline Water coverage(\%) & 68.1 & 3.26 & 13.81 \\
\hline Macrophyte coverage (\%) & 5.0 & 0.67 & 2.85 \\
\hline Depth(m) & 2.8 & 0.07 & 0.28 \\
\hline Temp (Air) ${ }^{\circ} \mathrm{C}$ & 26.1 & 0.64 & 2.70 \\
\hline Temp (Water) ${ }^{\circ} \mathrm{C}$ & 25.1 & 0.61 & 2.60 \\
\hline Water reaction(pH) & 8.0 & 0.07 & 0.28 \\
\hline Specific conductivity ( $\mu$ S/cm) & 263.7 & 8.35 & 35.41 \\
\hline Dissolved oxygen (ppm) & 7.5 & 0.13 & 0.53 \\
\hline Free Carbon di Oxide (ppm) & 1.1 & 0.21 & 0.90 \\
\hline Total Alkalinity (ppm) & 1.3 & 0.97 & 4.12 \\
\hline Total Hardness (ppm) & 105.3 & 3.20 & 13.57 \\
\hline Calcium (ppm) & 39.7 & 0.93 & 3.93 \\
\hline Magnesium(ppm) & 1.9 & 0.39 & 1.64 \\
\hline Chloride (ppm) & 20.0 & 1.03 & 4.37 \\
\hline Nitrate - N (ppm) & 98.4 & 11.95 & 50.71 \\
\hline Phosphate-phosphorus (ppm) & 143.0 & 23.21 & 98.45 \\
\hline Silicate-silica (ppm) & 7.1 & 0.52 & 2.19 \\
\hline
\end{tabular}


Table 2

Descriptive statistics of water quality parameters of Kole

\begin{tabular}{|llll|}
\hline Parameters & Mean & SE & SD \\
\hline Transparency $(\mathrm{m})$ & 1.2 & 0.1 & 0.3 \\
\hline Water coverage(\%) & 0.6 & 0.04 & 0.2 \\
\hline Macrophyte coverage (\%) & 0.4 & 0.03 & 0.1 \\
\hline Depth(m) & 60.9 & 2.3 & 9.8 \\
\hline Temp (Air) ${ }^{\circ} \mathrm{C}$ & 34.9 & 2.6 & 11.0 \\
\hline Temp (Water) ${ }^{\circ} \mathrm{C}$ & 0.02 & 0.001 & 0.004 \\
\hline Water reaction(pH) & 67.8 & 3.2 & 13.7 \\
\hline Specific conductivity ( $\mu \mathrm{S} / \mathrm{cm})$ & 16.2 & 1.2 & 5.0 \\
\hline Dissolved oxygen (ppm) & 2.2 & 0.1 & 0.5 \\
\hline Free Carbon di Oxide (ppm) & 27.5 & 1.1 & 4.6 \\
\hline Total Alkalinity (ppm) & 26.6 & 1.0 & 4.4 \\
\hline Total Hardness (ppm) & 7.9 & 0.1 & 0.2 \\
\hline Calcium (ppm) & 472.3 & 11.0 & 46.5 \\
\hline Magnesium(ppm) & 7.7 & 0.1 & 0.5 \\
\hline Chloride (ppm) & 1.3 & 0.3 & 1.3 \\
\hline Nitrate - N (ppm) & 145.2 & 2.5 & 10.5 \\
\hline Phosphate-phophorus (ppm) & 149.6 & 2.4 & 10.3 \\
\hline Silicate-silica (ppm) & 34.8 & 1.1 & 4.7 \\
\hline
\end{tabular}


Table 3

Diversity of phytoplankton in selected beels (floodplain wetlands) of west Bengal

\begin{tabular}{|ll|}
\hline Myxophyceae & Pandorina morum $(\mathrm{S}, \mathrm{K})$ \\
\hline Anabaena spiroides $(\mathrm{S}, \mathrm{K})$ & Pediastrum duplex $(\mathrm{S}, \mathrm{K})$ \\
\hline Aphanocapsa roeseana $(\mathrm{S}, \mathrm{K})$ & Scenedesmus obliqumus $(\mathrm{S}, \mathrm{K})$ \\
\hline Aphanothece pallida $(\mathrm{S}, \mathrm{K})$ & Spirogyra maxima $(\mathrm{S}, \mathrm{K})$ \\
\hline Chroococcus minutus $(\mathrm{S}, \mathrm{K})$ & Staurasterum orbiculare $(\mathrm{S})$ \\
\hline Cylindrospermum sp $(\mathrm{S}, \mathrm{K})$ & Stigoclonium sp $(\mathrm{S}, \mathrm{K})$ \\
\hline Gleocapsa sp $(\mathrm{S}, \mathrm{K})$ & Tetraedon sp $(\mathrm{SK})$ \\
\hline Gloeotrichia echinulat $(\mathrm{S}, \mathrm{K})$ & Tetraspora gelatinosa $(\mathrm{S})$ \\
\hline Lyngbya birgei $(\mathrm{S}, \mathrm{K})$ & Ulothrix zonata $(\mathrm{S}, \mathrm{K})$ \\
\hline Merismopedia minima $(\mathrm{S}, \mathrm{K})$ & Westella botryoides $(\mathrm{K})$ \\
\hline Microcystis aeruginosa $(\mathrm{S}, \mathrm{K})$ & Volvox areus $(\mathrm{S}, \mathrm{K})$ \\
\hline Nostoc linckia $(\mathrm{S}, \mathrm{K})$ & Bacillariophyceae \\
\hline Oscillatoria rubescens $(\mathrm{S}, \mathrm{K})$ & Amphora coffeaeformis $(\mathrm{S}, \mathrm{K})$ \\
\hline Phormidium inundatum $(\mathrm{S}, \mathrm{K})$ & Cyclotella meneginiyana $(\mathrm{S}, \mathrm{K})$ \\
\hline Rivullaria aquatica $(\mathrm{K})$ & Cymbella lanceolata $(\mathrm{S})$ \\
\hline Spirulina princeps $(\mathrm{S}, \mathrm{K})$ & Eunotia pectinalis $(\mathrm{S})$ \\
\hline Actinasitum gracillinum $(\mathrm{S}, \mathrm{K})$ & Fragillaria brevistriata $(\mathrm{S})$ \\
\hline Eudorina elegans $(\mathrm{S}, \mathrm{K})$ & Gomphonema lanceolatum $(\mathrm{S}, \mathrm{K})$ \\
\hline Ankistrodesmus falcatus $(\mathrm{S}, \mathrm{K})$ & Gyrosigma acuminatum $(\mathrm{S}, \mathrm{K})$ \\
\hline Asterococcus limneticus $(\mathrm{S}, \mathrm{K})$ & Melosira granulate $(\mathrm{S}, \mathrm{K})$ \\
\hline Characium augustum $(\mathrm{K})$ & Navicula radiosa $(\mathrm{S}, \mathrm{K})$ \\
\hline Chlorella vulgaris $(\mathrm{S}, \mathrm{K})$ & Nitzschia sigmoidia $(\mathrm{S}, \mathrm{K})$ \\
\hline Chlorococcum infusionum $(\mathrm{S})$ & Pinnularia major $(\mathrm{S}, \mathrm{K})$ \\
\hline Cladophora sp $(\mathrm{S}, \mathrm{K})$ & Rhopalodia gibba $(\mathrm{S}, \mathrm{K})$ \\
\hline Closterium parvulum $(\mathrm{S}, \mathrm{K})$ & Surirella sp $(\mathrm{S}, \mathrm{K})$ \\
\hline Cosmerium bengalicum $(\mathrm{S}, \mathrm{K})$ & Synedra capitata $(\mathrm{S}, \mathrm{K})$ \\
\hline
\end{tabular}

S = Saguna Floodplain wetland, $\mathrm{K}=$ Kole Floodplain wetland 


\begin{tabular}{|ll|}
\hline Myxophyceae & Pandorina morum (S,K) \\
\hline Crucigenia quadrata $(\mathrm{S}, \mathrm{K})$ & Euglenophyceae \\
\hline Dictyosphaerium pulchellum $(\mathrm{S})$ & Euglena viridis $(\mathrm{S})$ \\
\hline Euastrum spinulosum $(\mathrm{S}, \mathrm{K})$ & Phacus caudate $(\mathrm{S}, \mathrm{K})$ \\
\hline Hydrodiction idium $(\mathrm{S}, \mathrm{K})$ & Dinophyceae \\
\hline Micrasterius agardh $(\mathrm{S}, \mathrm{K})$ & Ceratium macroceros $(\mathrm{S})$ \\
\hline Mougeotia genuflexa $(\mathrm{S}, \mathrm{K})$ & Xanthophyceae \\
\hline Oedogonium australe $(\mathrm{S}, \mathrm{K})$ & Botrydium granulatum $(\mathrm{S}, \mathrm{K})$ \\
\hline Oocystis crassa $(\mathrm{S})$ & Tribonema vulgare $(\mathrm{K})$ \\
\hline $\mathrm{S}=$ Saguna Floodplain wetland, $\mathrm{K}=$ Kole Floodplain wetland \\
\hline
\end{tabular}

Table 4

Descriptive statistics of Phytoplankton data of Saguna

\begin{tabular}{|lllll|}
\hline SI. No. & Parameters & Mean & SE & SD \\
\hline 1. & Total Plankton NO & 1849.6 & 92.36 & 391.85 \\
\hline 2. & Phytoplankton No & 1543.2 & 75.90 & 322.01 \\
\hline 3. & Myxophyceae No & 404.5 & 28.23 & 119.75 \\
\hline 4. & Chlorophyceae No & 355.1 & 44.29 & 187.89 \\
\hline 5. & Bacillariophyceae No & 529.8 & 20.22 & 85.80 \\
\hline 6. & Euglenoida No & 131.4 & 12.91 & 54.78 \\
\hline 7. & Dinophyceae No & 83.6 & 9.64 & 40.88 \\
\hline 8. & Xanthophyceae No & 38.8 & 5.67 & 24.04 \\
\hline
\end{tabular}


Table 5

Descriptive statistics of Phytoplankton data of Kole

\begin{tabular}{|lllll|}
\hline SI. No. & Parameters & Mean & SE & SD \\
\hline 1. & Total Plankton NO & 1111.8 & 56.4 & 239.3 \\
\hline 2. & Phytoplankton No & 1052.0 & 60.4 & 256.1 \\
\hline 3. & Myxophyceae No & 295.7 & 23.5 & 99.8 \\
\hline 4. & Chlorophyceae No & 243.7 & 28.2 & 119.6 \\
\hline 5. & Bacillariophyceae No & 316.5 & 26.0 & 110.3 \\
\hline 6. & Euglenoida No & 93.6 & 9.7 & 41.3 \\
\hline 7. & Dinophyceae No & 78.6 & 9.9 & 42.1 \\
\hline 8. & Xanthophyceae No & 23.9 & 4.3 & 18.1 \\
\hline
\end{tabular}

Table 6

Diversity of zooplankton in selected beels (floodplain wetlands) of west Bengal

\section{Zooplankton}

\begin{tabular}{lll} 
Copepod & Rotifer & Protozoa \\
\hline Nauplii larvae $(\mathrm{S}, \mathrm{K})$ & Asplanchna intaonedia $(\mathrm{S}, \mathrm{K})$ & Arcella discoides $(\mathrm{S}, \mathrm{K})$ \\
\hline Cyclops larvae $(\mathrm{S}, \mathrm{K})$ & Brachionus caudatus $(\mathrm{S}, \mathrm{K})$ & Centropyxis aculeata $(\mathrm{S}, \mathrm{K})$ \\
\hline Cladocera & Filinia longiseta $(\mathrm{S}, \mathrm{K})$ & Difflugia rubsence $(\mathrm{S})$ \\
\hline Daphnia pulex $(\mathrm{S}, \mathrm{K})$ & Keratella tropica $(\mathrm{S}, \mathrm{K})$ & Vorticella sp $(\mathrm{S})$ \\
\hline Ceriodaphnia rigaudi $(\mathrm{S}, \mathrm{K})$ & Lecane paxiana $(\mathrm{S}, \mathrm{K})$ & \\
\hline Moina brachiata $(\mathrm{S}, \mathrm{K})$ & Monostylla closterocera $(\mathrm{S}, \mathrm{K})$ & \\
\hline Bosmina longirostris $(\mathrm{S}, \mathrm{K})$ & Nathalca $s p(\mathrm{~S}, \mathrm{~K})$ & \\
\hline & Polyarthra $s p(\mathrm{~S}, \mathrm{~K})$ & \\
\hline & Platysis $s p(\mathrm{~S}, \mathrm{~K})$ & \\
\hline S = Saguna Floodplain wetland, $\mathrm{K}=\mathrm{Kole} \mathrm{Floodplain}$ wetland & \\
\hline
\end{tabular}


Table 7

Descriptive statistics of Zooplankton data of Saguna

\begin{tabular}{|llll|}
\hline Parameters & Mean & SE & SD \\
\hline ZPNO & 310.4 & 30.78 & 130.59 \\
\hline COPNO & 103.6 & 11.83 & 50.17 \\
\hline ROTNO & 105.2 & 12.27 & 52.04 \\
\hline CLADONO & 53.3 & 6.97 & 29.59 \\
\hline PROTONO & 32.8 & 4.56 & 29.00 \\
\hline MISCNO & 15.8 & 1.95 & 8.29 \\
\hline
\end{tabular}

Table 8

Descriptive statistics of Zooplankton data of Kole

\begin{tabular}{|llll|}
\hline Parameters & Mean & SE & SD \\
\hline ZPNO & 82.8 & 4.8 & 20.4 \\
COPNO & 31.9 & 3.3 & 14.2 \\
\hline ROTNO & 19.7 & 1.1 & 4.9 \\
\hline CLADONO & 17.1 & 1.6 & 7.0 \\
\hline PROTONO & 9.1 & 0.9 & 3.7 \\
\hline MISCNO & 5.0 & 0.6 & 2.4 \\
\hline
\end{tabular}


Table 9

Diversity of periphyton in selected beels (floodplain lakes) of West Bengal, (2011-13)

\begin{tabular}{|c|c|c|c|}
\hline SI. No. & Myxophyceae & SI. No. & Bacillariophyceae \\
\hline 1 & Anabaena spiroides $(\mathrm{S}, \mathrm{K})$ & 24 & Amphora coffeaeformis $(\mathrm{S}, \mathrm{K})$ \\
\hline 2 & Aphanocapsa crassa $(\mathrm{S}, \mathrm{K})$ & 25 & Closterum parvulum $(\mathrm{S}, \mathrm{K})$ \\
\hline 3 & Chroococcus minutus $(\mathrm{S}, \mathrm{K})$ & 26 & Cosmarium bengalicum $(\mathrm{S}, \mathrm{K})$ \\
\hline 4 & Cylindrospermum muscicola $(\mathrm{S}, \mathrm{K})$ & 27 & Cyclotella meneginiyana $(\mathrm{S}, \mathrm{K})$ \\
\hline 5 & Gleocapsa sp (S,K) & 28 & Cymbella lanceolata $(\mathrm{S}, \mathrm{K})$ \\
\hline 6 & Gleotrichia echinulat $(\mathrm{S}, \mathrm{K})$ & 29 & Diatoma $s p(\mathrm{~S}, \mathrm{~K})$ \\
\hline 7 & Lyngbya birgei (S,K) & 30 & Diploneis ovalis $(\mathrm{S}, \mathrm{K})$ \\
\hline 8 & Merismopedia minima $(\mathrm{S}, \mathrm{K})$ & 31 & Gomphonema lanceolatum (S,K) \\
\hline 9 & Nostoc linckia $(\mathrm{S}, \mathrm{K})$ & 32 & Gyrosigma acuminatum (S,K) \\
\hline 10 & Oscillatoria rubescens (S,K) & 33 & Melosira granulate(SK) \\
\hline \multirow[t]{2}{*}{11} & Phormidium inundatum (S,K) & 34 & Navicula radiosa $(\mathrm{S}, \mathrm{K})$ \\
\hline & Chlorophyceae & 35 & Nitzschia sigmoidia (S,K) \\
\hline 12 & Chlorella vulgaris $(\mathrm{S}, \mathrm{K})$ & 36 & Pinnularia major (S,K) \\
\hline 13 & Closteridium difficile $(\mathrm{S}, \mathrm{K})$ & 37 & Rhopalodia gibba (S,K) \\
\hline 14 & Crucigenia quadrata $(\mathrm{S}, \mathrm{K})$ & 38 & Synedra capitata (S,K) \\
\hline 15 & Mougeotia genuflexa $(\mathrm{S}, \mathrm{K})$ & 39 & Euglena viridis $(\mathrm{S}, \mathrm{K})$ \\
\hline 16 & Oedogonium australe $(\mathrm{S}, \mathrm{K})$ & 40 & Phacus caudate $(\mathrm{S}, \mathrm{K})$ \\
\hline 17 & Pediastrum duplex $(\mathrm{S}, \mathrm{K})$ & 41 & Tribonema vulgare $(\mathrm{S}, \mathrm{K})$ \\
\hline 18 & Scenedesmus obliqumus $(\mathrm{S}, \mathrm{K})$ & 42 & Dinobryon divergens $(\mathrm{S}, \mathrm{K})$ \\
\hline 19 & Spirogyra maxima $(\mathrm{S}, \mathrm{K})$ & & Animalcules \\
\hline 20 & Staurastrum orbiculare (S) & 43 & Difflugia humilis (S,K) \\
\hline 21 & Tetraedon sp (S,K) & 44 & Actinospherium $s p(\mathrm{~S}, \mathrm{~K})$ \\
\hline 22 & Ulothrix zonata $(\mathrm{S}, \mathrm{K})$ & 45 & Conochilus unicornis $(\mathrm{S}, \mathrm{K})$ \\
\hline \multirow[t]{2}{*}{23} & Zygnema sp $(\mathrm{S}, \mathrm{K})$ & 46 & Brachionus falcatus $(\mathrm{S}, \mathrm{K})$ \\
\hline & & 47 & Keratella tropica $(\mathrm{S}, \mathrm{K})$ \\
\hline
\end{tabular}


Table 10

Descriptive statistics of Periphyton data of Saguna

\begin{tabular}{|llll|}
\hline Parameters & Mean & SE & SD \\
\hline PERITOT & 434.4 & 37.88 & 160.70 \\
\hline PMYXONo & 99.0 & 8.10 & 34.38 \\
\hline PCHLORONo & 87.6 & 5.78 & 24.54 \\
\hline BACILNO1 & 139.1 & 14.61 & 61.98 \\
\hline PMISCNO & 108.9 & 13.52 & 57.37 \\
\hline
\end{tabular}

\section{Table 11}

Descriptive statistics of Periphyton data of Kole

\begin{tabular}{|llll|}
\hline Parameters & Mean & SE & SD \\
\hline PERITOT & 550.5 & 51.2 & 217.2 \\
\hline PMYXONo & 189.4 & 23.3 & 98.8 \\
\hline PCHLORONo & 106.5 & 6.3 & 26.7 \\
\hline BACILNo1 & 158.2 & 18.9 & 80.3 \\
\hline PMISCNO & 96.4 & 5.7 & 24.0 \\
\hline
\end{tabular}


Table 12

Diversity of macrophytes in selected beels (floodplain wetlands) of West Bengal

\begin{tabular}{|c|c|c|c|}
\hline Macrophyte & Family & Occurance & $\%$ \\
\hline Floating & & & $\begin{array}{l}50- \\
60\end{array}$ \\
\hline Eichhornia crasipes $(S, K)$ & Pontederiaceae & Floating & \\
\hline Azolla pinnata $(S, K)$ & Azollaceae & Floating & \\
\hline Pistia stratiotes $(S, K)$ & Araceae & Floating & \\
\hline Lemna minor $(S, K)$ & Lemnaceae & Floating & \\
\hline Lemna perpusilla (S) & Lemnaceae & Floating & \\
\hline Spirodella polyrhiza (S) & Lemnaceae & Floating & \\
\hline Wolfia arhiza $(S, K)$ & Lemnaceae & Floating & \\
\hline Trapa natans $(S, K)$ & Trapaceae & Floating & \\
\hline Rooted floating & & Floating & \\
\hline Nymphoides indicum $(S, K)$ & Gentianaceae & Floating & \\
\hline Nelumbo nucifera $(S, K)$ & $\begin{array}{l}\text { Brassicaceae } \\
\text { (Cruciferae) }\end{array}$ & Floating & \\
\hline Nymphaea stellate $(S, K)$ & Nymphaeaceae & Floating & \\
\hline Nymphaea nauchali $(S, K)$ & Nymphaeaceae & Floating & \\
\hline Euryale ferox $(S, K)$ & Nymphaeaceae & Floating & \\
\hline Potamogeton nodosus $(S, K)$ & Potamogetonaceae & Floating & \\
\hline $\begin{array}{l}\text { Myriophylum tuberculatum } \\
(S, K)\end{array}$ & Haloragaceae & Floating & \\
\hline Aponogeton natans $(S, K)$ & Aponogetonaceae & Floating & \\
\hline Submerged & & & $\begin{array}{l}15- \\
20\end{array}$ \\
\hline Hydrilla verticillata $(S, K)$ & Hydrocharitaceae & Submerged & \\
\hline Ceratophyllum demersum $(S, K)$ & Ceratophyllaceae & Submerged & \\
\hline Vallisneria spiralis $(S, K)$ & Hydrocharitaceae & Submerged & \\
\hline Potamogeton pectinatus $(S, K)$ & Potamogetonaceae & Submerged & \\
\hline Najas minor $(S, K)$ & Hydrocharitaceae & Submerged & \\
\hline
\end{tabular}




\begin{tabular}{|c|c|c|c|}
\hline Macrophyte & Family & Occurance & $\%$ \\
\hline Chara vulgaris $(S)$ & Characeae & Submerged & \\
\hline Chara zeylanica $(S, K)$ & Characeae & Submerged & \\
\hline Chara nuda $(S, K)$ & Characeae & Submerged & \\
\hline Marginal (prostrate emergent) & & & $\begin{array}{l}10- \\
15\end{array}$ \\
\hline Marselia quadrifolia $(S, K)$ & Marseliaceae & $\begin{array}{l}\text { Marginal(prostrate } \\
\text { emergent) }\end{array}$ & \\
\hline Marselia minuta $(S)$ & Marseliaceae & $\begin{array}{l}\text { Marginal(prostrate } \\
\text { emergent) }\end{array}$ & \\
\hline Ipomoea aquatic $(S, K)$ & Convolvulaceae & $\begin{array}{l}\text { Marginal(prostrate } \\
\text { emergent) }\end{array}$ & \\
\hline Enhydra fuctuans(S) & Compositae & $\begin{array}{l}\text { Marginal(prostrate } \\
\text { emergent) }\end{array}$ & \\
\hline Marginal (erect element) & & & $1-5$ \\
\hline Acorus calamus (S) & Acoraceae & Marginal (erect element) & \\
\hline Colocasia esculenta $(S, K)$ & Araceae & Marginal (erect element) & \\
\hline Cyperus difformis $(S, K)$ & Cyperaceae & Marginal (erect element) & \\
\hline Cyperus procerus $(S, K)$ & Cyperaceae & Marginal (erect element) & \\
\hline Limnophyla indica(S,K) & Scrophulariaceae & Marginal (erect element) & \\
\hline
\end{tabular}


Table 13

Diversity of Macrobenthic Invertebrate in selected floodplain wetlands of west Bengal

\begin{tabular}{|llll|}
\hline SI. No. & Gastropods & Sl. No. & Bivalve \\
\hline 1. & Planorbis compressus $(S, K)$ & 16 & Aelosoma bengalensis $(S, K)$ \\
\hline 2. & Vivipora bengalenis $(S, K)$ & 17 & Nais simplex $(S, K)$ \\
\hline 3. & Pila globosa $(S, K)$ & 18. & Nais pectinata $(S)$ \\
\hline 4. & Bellamya bengalensis $(S, K)$ & 19 & Limnodrilus hoffmeisteri $(S, K)$ \\
\hline 5. & Digniostemma pulchella $(S, K)$ & 20 & Tubifex tubifex $(S, K)$ \\
\hline 6. & Lymnea acuminate $(S, K)$ & 21 & Chaetogastor orientalis $(S, K)$ \\
\hline 7. & Indoplanorbis exustus $(S, K)$ & & Chironomid \\
\hline 8. & Gobia orcula $(S, K)$ & 22 & Chironomus sp $(S, K)$ \\
\hline 9. & Orbicular striatella $(S, K)$ & & Miscellaneous organism \\
\hline 10. & Gyraulus convexiusculus $(S, K)$ & 23 & Hellobdella triserialis $(S)$ \\
\hline 11. & Thiara acuminate $(S)$ & 24 & Nymphs of dragon fly $(S, K)$ \\
\hline & Bivalve & 25 & Damsel fly $(S, K)$ \\
\hline 12. & Lamellidens marginalis $(S)$ & 26 & Stone fly $(S, K)$ \\
\hline 13 & Unio tumidus $(S, K)$ & 27 & May fly $(S, K)$ \\
\hline 14. & Parreysia fevidens-plagiasoma $(S, K)$ & 28 & Eeucypris affinis $(S, K)$ \\
\hline 15. & Parreysia radiatula caerulea $(S, K)$ & 29 & Stenocypris sp. $(S, K)$ \\
\hline S = Saguna Floodplain wetland, $K=$ Kole Floodplain wetland \\
\hline
\end{tabular}

Table 14

Descriptive statistics of Benthos data of Saguna

\begin{tabular}{|llll|}
\hline Parameters & Mean & SE & SD \\
\hline Benthos (Total No) & 336.9 & 26.17 & 111.01 \\
\hline Gastropod No & 290.3 & 27.43 & 116.39 \\
\hline Bivalve No & 12.9 & 2.25 & 9.53 \\
\hline Oligochaete No & 17.6 & 4.13 & 17.52 \\
\hline Chironomids No & 10.2 & 2.69 & 11.40 \\
\hline Other No & 5.9 & 0.86 & 3.67 \\
\hline
\end{tabular}


Table 15

Descriptive statistics of Benthos data of Kole

\begin{tabular}{|llll|}
\hline Parameters & Mean & SE & SD \\
\hline Benthos (Total No) & 383.6 & 29.2 & 124.1 \\
\hline Gastropod No & 317.1 & 28.9 & 122.8 \\
\hline Bivalve No & 16.5 & 2.3 & 9.6 \\
\hline Oligochaete No & 21.2 & 4.5 & 19.2 \\
\hline Chironomids No & 15.3 & 3.8 & 16.1 \\
\hline Other No & 13.5 & 1.2 & 4.9 \\
\hline
\end{tabular}

Table 16

Descriptive statistics of Productivity data of Saguna

\begin{tabular}{|llll|}
\hline Parameters & Mean & SE & SD \\
\hline Gross Primary Productivity & 0.5 & 0.04 & 0.15 \\
\hline Net Primary Productivity & 0.3 & 0.03 & 0.12 \\
\hline Assimilation efficiency & 57.8 & 1.74 & 7.37 \\
\hline Respiration & 28.1 & 1.52 & 6.43 \\
\hline Photosynthesis Respiration Ratio & 0.0 & 0.00 & 0.00 \\
\hline
\end{tabular}

Table 17

Descriptive statistics of Productivity data of Kole

\begin{tabular}{|llll|}
\hline Parameters & Mean & SE & SD \\
\hline Gross Primary Productivity & 0.6 & 0.0 & 0.2 \\
\hline Net Primary Productivity & 0.4 & 0.0 & 0.1 \\
\hline Assimilation efficiency & 60.9 & 2.3 & 9.8 \\
\hline Respiration & 34.9 & 2.6 & 11.0 \\
\hline Photosynthesis Respiration Ratio & 0.0 & 0.0 & 0.0 \\
\hline
\end{tabular}

\section{Declarations}

\section{Acknowledgments}

The authors express their thankfulness to Dr. A. P. Sharma, Director, Central Inland Fisheries Research Institute for his encouragement for the study. 


\section{References}

1. ]ha, B.C., 1997. Salient ecological features of mauns and charus of Bihar. Jn Fisheries enhancement of small reservoirs and floodplain Jakes in Indi1:1. (eds. V. V. Sugunan \& NL Sinha). CIFRI Bull. 75: 167-174. 21

2. AKM Fazlur Rahaman, MA Mansur, M Shahidur Rahman. "Monthly and diurnal variations of limnological conditions of two ponds", International Journal of Agricultural Research, Innovation and Technology, 2017

3. Alikunhi., K. H., Choudhury, $\mathrm{H}$ and Ramachandra, V., 1955. On the mortality of carp fry in nursery ponds and role of planktons in their survival and growth. Indian j. Fish. 3(2): 257-313 pp.

4. American Public Health Association (APHA), 1985. Standard methods for the examination of water, sewage and industrial wastes, New York: 552 p.

5. American Public Health Association. (1995). Washington, DC, USA, pp: 1-55, 2-90, 4180, 5-65 and 10153.

6. Ayyappan, S. 2011. Floodplain Wetlands of India. In: Handbook of Fisheries and Aquaculture. Indian Council of Agricultural Research. New Delhi. pp. 275-301.

7. Banerjea, S. M. 1967. Water quality and soil condition of fish ponds in some states of India in relation to fish production. Indian J. Fish.,14(1\&2): 115-144.

8. Banerjea, S.M., 1967. \'Ylater quality and soil condition of fish ponds in some states of India in relation to fish production. Indian j Fish.) 14(1\&2): 115-144.

9. Battis, S. K., 1992. Freshwater zooplankton of India. Oxford and JBH Publishing Company. New Delhi.

10. Beaver, J.R., A.M. Miller-Lanke, and J.K. Acton, 1998. Mid-Summer zooplankton assemblages in four types of wetlands in the upper midwest, USA, Hydrobiologia) 380: 209-220.

11. Bhowmick, M. L. 1968. Environmental factors affecting fish food in freshwater fisheries, Kalyani, West Bengal, India, Ph. D. Thesis, University of Kalyani (unpublished): 238 pp.

12. Bhowmik, M.L., 1988. Limnology and productivity of some heels and baors of West Bengal with reference to recent development, Environ. \& Ecol., 6(1): 42-47.

13. Bhowmik., M. L.1988. Limnology and productivity of some beels and baors of West Bengal with reference to recent development, Environ. \& Ecol., 6(1):42-47.

14. Boneto, C. A., Zalocar, Y. and Lancelle. G. H., 1984. A limnological study of an oxbow lake covered by Eichhornea crassipes in the Parana River. Verh. Int. Limnol., 22: 315-318 pp.

15. Boyd, C. E., 1971. The dynamics of dry matter and chemical substances of Juncus effuses population. Amer. Midl. Natur., 86: 28-45.

16. Bray. J. R. and C.T. Curtis, 1957. An ordination of the upland forest communities of southern Wisconsin. Ecol. 1!1onogr. 27: 325 - 490. 
17. Brent B. Wolfe. "Classification of hydrological regimes of northern floodplain basins (PeaceAthabasca Delta, Canada) from analysis of stable isotopes $(\delta 180, \delta 2 \mathrm{H})$ and water chemistry", Hydrological Processes, 01/15/2007

18. Bristow, J. M., 1975. The structure and function of roots in aquatic vascular plants, The development and function roots (eds. Torrey J. G. and Clarkson D.)Academic Press London. 221-236 pp.

19. Brown, S. L. 1981. A comparison of the structure, primary productivity, and transpiration of cypress ecosystems in Florida. Ecological Monographs 51 4:403-427.

20. Cairns, J., 1965. The effect of increased temperature upon the aquatic organism, Proc. $10^{\text {th }}$ Indus. Waste Conf., Purdue Univ., Eng. Bull. 40(1): 346 pp.

21. Camargo, A. F. M. and Florentino, E. R., 2000. Population dynamics and net primary production in the aquatic macrophyte Nymphaea rudgeana in a lotic environment of the Itanhaem River basin (SP, Brazil). Rev. Brasil. Biol., 60 (1): 83-92.

22. Carney, H. J., Binford, M. W., Marin, R. R. and C. R. Goldman 1993. Nitrogen and phosphorus dynamics and retention in ecotones of Lake Titicaca, Bolivia/Peru, Hydrobiologia, 251:39-47

23. Casanova, M. T. \& Brock, M. A. (2000) How do depth, duration, and frequency of flooding influence the establishment of wetland plant communities? Plant Ecol. 147, 237-250.

24. Chambers. P. A., Prepas E. E., Bothwell, and Hamilton, H. R. 1989. Root versus shoots in nutrient uptake by aquatic macrophytes in flowing waters. Can.J. Fish. Aquat. Sci., 46: 435-439 pp.

25. Chu, S. P., 1943. The influence of mineral composition of the medium on the growth of planktonic algae. Part II. The influence of the concentration of inorganic nitrogen and phosphate phosphorus. $j$ Ecol., 31: 109-148.

26. Clesceri, L. S., A. E. Greenberg, and A. D. Eaton. 1998. Standard methods for the examination of water and wastewater. American Public Health Association. Washington, D.C.

27. Croome, R. L. and P.A. Tyler, 1975. Phytoplankton biomass and primary production of lake Leaker and Tooma lake, Tasmania, Hydrobiologia) 46(4): 435-445.

28. Da Silva, C. J., and F. A. Esteves., 1993. Biomass of three macrophytes in the pantanal of the Mato Grosso, Brazil. Internat. J. Ecol. Environ. Sci., 19:11-23 pp.

29. Das, A. K. 2000. Energy dynamics in the beels of West Bengal. Proc. Nat. Acad. Sci. India, 70(B), II: 139-145 pp.

30. Das, S. M. and Srivastava, V. K., 1956. Quantitative studies on freshwater plankton. Part II. Correlation between plankton and hydrobiological factors and hydrological factors. In: Proc. Nat. Acad. Sci., India, pp. 243-254.

31. Dede, A.N. and Deshmukh, A.L. (2015). Study on Zooplankton Composition and Seasonal Variation in Bhima River Near Ramwadi Village, Solapur District (Maharashtra), India. Int.J.Curr.Microbiol.App.Sci; 4(3): 297-306.

32. Denny, P., 1995. Wetlands and biodiversity. In: Conservation and Sustainable Use of Floodplain Wetlands (ed. Holmes, J. R.). Asian Wetland Bureau, Kuala Lampur, pp. 81-83. 
33. Devashish Kar. "Community-based fisheries management in different continents and countries across the world", Elsevier BV, 2021

34. Donk, S. S., Dixit, A. S. and R. D. Evans. 1993. Chyysophyte scale in lake sediments provides evidence of recent acidification in two Quebec (Canada) lakes. Water, Air and Soil pollution.38: 97-104 pp.

35. Elhance, D.N. and V. Elhance, 1992. Fundamentals of statistics, Kitab Mahal, Allahabad. 11.1-11. 74.

36. Ellis, M. M., B.A. Wesfall, and M.D. Ellis, 1948. Determination of water quality, Research Report no. 9, Fish and W1 Jdlife Service. US A.

37. felch, P.S., 1952. Limnology (2nd ed.) Mc Graw-Hill, New York. 538 p.

38. felcome, R.I., 1979. Fisheries Ecology of Floodplain Rivers, Longman Ltd. 317 p.

39. Fisher, R.A. and F. Yates, 1974. Statistical Tables for Biological, Agricultural and Medical Research, Longman Group Ltd. 146 p.

40. Furch, K., 1984. Seasonal variation of the major cation content of the Varzea-Lake Camaleao, Middle Amazon, Brazil in 1981 and 1982. Verh. Int. Verein. Limnol., 22: 1288-1293 pp.

41. Ganapati, S. V. and A. Sreenivasan, 1970. Energy flow in a natural aquatic ecosystem in India. Arch.Hyrobiol., 66_(4): 458-498.

42. Goldman, C. R., and A. J. Horne 1983. Limnology. McGraw-Hill International Book Company, 464 pp.

43. Goswami, A.P. and Mankodi, P.C. (2012). Study on Zooplankton of Fresh Water Reservoir Nyari - II Rajkot district, Gujarat, India. ISCA Journal of Biological Sciences; 1(1):30-34.

44. Goswami, A.P. and Mankodi, P.C. (2012). Study on Zooplankton of Fresh Water Reservoir Nyari - II Rajkot district, Gujarat, India. ISCA Journal of Biological Sciences; 1(1):30-34.

45. Gunnison, D., and Barko., J. W. 1989. The rhizosphere ecology of submerged macrophytes. Water resource bull. 25: 193-201.

46. Hamilton, S.K. and Lewis, M.W.Jr., 1987. Causes of seasonality in the chemistry of a lake on the Orinoco River floodplain, Venezuela. Limnol. Oceanogr., 32:1277-1290 p p.

47. Hart, J. S., 1944. The circulation and respiratory tolerance of some Florida freshwater fishes. Proc.Fla.Acad. Sci., 7: 221-246.

48. Hutchinson, G.E., 1957. A Treatise on limnology, vol. I: Chapman Hall, London, 1015 p p.

49. Ismail, A. H., and Zaidin, S. A. (2015). A comparative study of Zooplankton diversity and abundance from three different types of a water body. 2nd International Conference on Agriculture, Environment and Biological Sciences (ICAEBS'15) August 16-17, 2015 Bali (Indonesia).

50. J. K. Jena. "Evaluation of production performance in carp polyculture with different stocking densities and species combinations", Journal of Applied Ichthyology, 6/2002

51. Jackson, M.L. (1973). Soil chemical analysis, Prentice Hall, Englewood Cliffs, New Jersey, USA.

52. Jackson, NLL., 1973. Soil chemical analysis, Premice Hall, Englewood Chile ", New Jersey, USA.

53. Jamil, K., 1993. The role of macrophytes in aquatic ecosystems. J. Freshwater Bioi., 5(2): 141-145. 
54. Jha, B.C. 1997. Fisheries of Muktapur Lake - a case study, p. 175-178. In V.V. Sugunan and M. Sinhan (eds.) Fisheries enhancement of small reservoirs and floodplain lakes in India. CICFRI, Barrackpore.

55. Jhingran, A.G. 1989. Strategies for development in beel fisheries. Training in Management of Beel (ox-bow) Fisheries. Central Inland Fisheries Research Institute, Barrackpore. Bull. No. 63:1-7.

56. Junk, W.J., 1986. Aquatic plants of the Amazon system. In: The Ecology of River Systems (ed., Davies, B.R and Walker, K.F.). Dr. W. Junk Publishers, Netherland, 319-337 p p.

57. Junk, W.J., Bayley, P.B. and R.E. Spark., 1989. The flood pulse concept in the river-floodplain system. In: proceeding of the 'International Large Rivers Symposium. Con. Spec. past. Fish. Aquat. Sci., 106:110-127 p p.

58. Junk., J. W. and M. T. F. Piedade., 1993. Biomass and primary production of Herbaceous plant communities in the Amazon Floodplain. Hydrobiologia, 263: 155-162 pp.

59. Kaliamurthy, M., 1978. Organic production in relation to environmental features nutrients and fish yield of lake Pulicat. J Inland Fish. Soc. India, 10: 68-75.

60. Kar, D. (2007). Fundamentals of Limnology and Aquaculture Biotechnology. Daya Publishing House, xiv+609.

61. Khan, M.A. and D.P. Zutshi, 1980. Primary productivity and trophic status of Kashmir Himalayan lake, Hydrobiol., 68(1): 3-8.

62. Kumar, K. 1985. Hydrobiological investigations of a freshwater beel with special reference to its fish production potentialities. Ph.D. Thesis, Bhagalpur University, Bihar, India (unpublished).

63. Kumar, Kuldip., 1985. Hydrobiological investigations of a freshwater bee! with special reference to its fish production potentialities. Ph.D. Thesis, Bhagalpur University, Bihar, India.

64. L. G. Ruwini Yasadari Perera. "A Preliminary Study on the Variation of Zooplankton Diversity, Abundance and Density in a Selected Branch of Diyawanna Oya Canal System", OUSL Journal, 2015

65. Laal, A. K., 1989. Association of macroinvertebrates with macrophytes in some tropical plants. J. Inland Fish. Soc. India, 21(10). 20-25 pp.

66. Laal, A.K., 1981. Studies on the ecology and productivity of swamps in North Bihar in relation to the production of fishes and other agricultural commodities. Ph.D. Thesis, Bhagalpur University, Bihar, India.

67. Lackey, J.B., 1973. Bottom fauna changes during artificial reservoir desertification, Wat Res., 7: 13491356.

68. Lahon, B., 1983. Limnology and Fisheries of some commercial beels Assam: 349 pp.

69. Michael, R. G., 1969. Seasonal trend in physic-chemical factors and plankton of freshwater pond and their role in fish culture. Hydrobiologia, 33 (1): 145-160.

70. Mitsch, W. J. 1995a. Restoration and creation of wetlands - providing the science and engineering basis and measuring success. Ecological Engineering 4: 61-64. 
71. Mitsch, W. J. 1995b. Restoration of our Lakes and Rivers with wetland - an important application of ecological engineering. Wat. Sci. Tech.31(8), 167-177.

72. Mohit Kumar Singh, A.K. Tripathi, V. Jeeva. "Limnological Study of Asan Wetland in Relation to Water Quality in Doon Valley, Uttarakhand, India", Asian Journal of Water, Environment and Pollution, 2016

73. Moitra, S. K. and Bhattacharjya, B. K., 1965. Some hydrobiological factors affecting plankton production in a fish pond in Kalyani, West Bengal, India. Ichthyologia, 4(1-2): 8-12.

74. Mukhopaclhyaya, M.K., 1997. Ecology of the beels in West Bengal. In: Fisheries enhancement of f1oodplains and their implications on fisheries. 1 Vfeenbana) Dept. of Fisheries, West Bengal. 11-14.

75. Munawar, M., 1970. Limnological studies on a freshwater pond of Hyderabad India. 1. The Biotope. Hydrobiologia, 35: 127-162.

76. Needham, J. G., and J. T. Lloyd. 1930. The life of the inland waters. C. C. Thomas Publishers, Baltimore, MD. 438 p.

77. Odum, E. P., 1983. Basic Ecology. Saunders College Publishing, Philadelphia, USA, 613 pp.

78. Parameswaran, S. and Vass, K. K. 1995. An overview of floodplain wetlands in West Bengal, pp. 52 66. In Howes, R. J. (ed). Conservation and sustainable use of floodplain wetlands. Asian Wetland Bureau, Kuala Lumpur.

79. Pennak, R. W., 1953. Freshwater invertebrates of the United States. The Ronald Press, Newyork, USA. Science Publishers, West Germany.

80. Quinn, G. P., Hillman, T. J. \& Cook, R, (2000) The response of macroinvertebrates to inundation in floodplain wetlands: a possible effect of river regulation? Regul. Rivers. Res. Manage. 16. 469-477.

81. R. George Michael. "Seasonal trends in physicochemical factors and plankton of a freshwater fishpond and their role in fish culture", Hydrobiologia, 1969

82. Rai, D. N., and Sharma, U. P., 1989. Zooplankton periodicity in weed infested wetlands of North Bihar. J. Freshwater Biol. 1(2): 161-166.

83. Reid G.K. (1961): Ecology of inland waters and estuaries. - Reinhold Publication Corporation, New York, USA

84. Saha, G. N., K. L.Sehgal, E. Mitra, and A.C. Nandy 1971. Studies on the seasonal and diurnal variations in Physico-chemical and biological conditions of a perennial pond. J. Inland Fish. Soc. India., 3: 79-102.

85. Saha, S. B., M. J. Bhagat and V. Pathak 1990.Ecological changes and its impact on the fish yield of Kulia beel in Ganga basin. J. Inland Fish.Soc. India.,22 (1\&2): 7-11.

86. SAS Institute Inc. 2010. SAS/STAT ® 9.2. User's Guide. Cary, NC: SAS Institute Inc.

87. Sharma, U. P., 1995. Role of macrophytes in the ecosystem of Kawar lake wetland(Begusarai), Bihar, India. J. Freshwater Biol.7(2): 123-128 pp.

88. Sinha, M., 2001. Reservoir-and important fishery resources of India and its utilization for increasing fish production in the country. In: Management of fisheries in small reservoirs. (ed. Utpal Bhaumik). CJFRJ Bull.) 106: 1-15. 
89. Sneclecor, G.W. and W.G. Cochran, 1967. Statistical method, Oxford and IBH Publishing Co., New Delhi, $593 \mathrm{p}$.

90. Sona Yengkokpam, Basanta Kumar Das, Dipesh Debnath, Pronob Das et al. "Effect of stocking density on growth and yield of Labeo bata fingerlings reared in cages", Aquaculture Reports, 2020

91. Sreenivasan, A., 1964. The limnology, primary production, and fish production in a tropical pond. Limnol. Oceanog 1; 9(3): 391-396.

92. Sreenivasan, A., 1968. The limnology and fish production in two ponds of Chingleput (Madras), Hydrobiologia, 32 (1-2): 131-137.

93. Sreenivasan. "Limnological Studies and Fish Yield in Three Upland Lakes of Madras State, India", Limnology and Oceanography, 1964.

94. Sugunan, V. V. and Bhattacharya, B. K. 2000. Ecology and fisheries of beels in Assam. CIFRI Bull. 104, pp 65.

95. Sugunan, V. V., Vinci, G. K., Bhattacharjya, B. K. and Hassan, M. A. 2000. Ecology and fisheries of beels in West Bengal. CIFRI Bull. 103.

96. Sugunan, V.V. and Mukhopadhyay, M., 1995. Conservation and Sustainable use of floodplain wetlands: Case studies of Bandardaha and Baloon beels. In: Howes, J. R., (Editor) Conservation and sustainable use of floodplain wetlands; Asian Wetland Bureau, Kualampur, AWB, Publication, Malaysia., 67-75 pp.

97. Sugunan, V.V., 1989. Limnological features of beels - biotic factors. In: Training in management of bee! (oxbow lake) fisheries. CIFRI Bull.) 63: 128-135.

98. Sugunan, V.V., G.K. Vinci, B.K. Bhattacharya, and A. Hassan, 2000. Ecology and fisheries of beels in West Bengal. CJFRI Bull.) 103: 53 p.

99. Talling, J.F. (1986). The seasonality of phytoplankton in African lakes. Hydrobiologia 138, 139-160.

100. Ward, H.B. and G.C. Whipple, 1992. Freshwater biology. (2nd Ed). (ed. W.T. Edmondson). Indian reprint, International Books \& Periodically Supply Service, New Delhi. 1247 p.

101. Wetzel, R. G. and Likens, G. E., 1991. Limnological analysis. W. B. Saunders Co., Philadelphia, 357 pp.

102. Wetzel, R. G., 2001. Limnology: lake and river ecosystems. San Diego: Academic Press. 1006p.

103. Yadav, Y.S., 1988. Riverine flood plain fishery resources. (eel. A.G. Jhingran \& V.V. Sugunan). CI.FRI Bull.) 57: 134-142.

104. Yadav, Y.S., R.K. Singh, M. Choudhury, and V. Kolekar, 1987. Limnology and productivity of Dighali beel(Assam). Trap. Ecol.) 28(2): 137-146.

105. Yadava, Y. S., 1987. Studies on the ecology of an ox-bow lake in context to the development of beels in Assam. Compendium: Workshop on the development of beel fishery in Assam, A.A.U, 21-22 April: 70-94 pp.

106. Yadava, Y. S., Singh, R. K., Choudhury, M and Kolekar, V., 1987. Limnology and productivity of Dighali beel (Assam). Trop. Ecol., 28(2): 137-146 pp. 


\section{Tables}

Table 1: Descriptive statistics of Water quality parameters data of Saguna

\begin{tabular}{|llll|}
\hline Parameters & Mean & SE & SD \\
\hline Transparency $(\mathrm{m})$ & 1.9 & 0.06 & 0.27 \\
\hline Water coverage(\%) & 68.1 & 3.26 & 13.81 \\
\hline Macrophyte coverage (\%) & 5.0 & 0.67 & 2.85 \\
\hline Depth(m) & 2.8 & 0.07 & 0.28 \\
\hline Temp (Air) ${ }^{\circ} \mathrm{C}$ & 26.1 & 0.64 & 2.70 \\
\hline Temp (Water) ${ }^{\circ} \mathrm{C}$ & 25.1 & 0.61 & 2.60 \\
\hline Water reaction(pH) & 8.0 & 0.07 & 0.28 \\
\hline Specific conductivity ( $\mu$ S/cm) & 263.7 & 8.35 & 35.41 \\
\hline Dissolved oxygen (ppm) & 7.5 & 0.13 & 0.53 \\
\hline Free Carbon di Oxide (ppm) & 1.1 & 0.21 & 0.90 \\
\hline Total Alkalinity (ppm) & 1.3 & 0.97 & 4.12 \\
\hline Total Hardness (ppm) & 105.3 & 3.20 & 13.57 \\
\hline Calcium (ppm) & 39.7 & 0.93 & 3.93 \\
\hline Magnesium(ppm) & 1.9 & 0.39 & 1.64 \\
\hline Chloride (ppm) & 20.0 & 1.03 & 4.37 \\
\hline Nitrate - N (ppm) & 98.4 & 11.95 & 50.71 \\
\hline Phosphate-phosphorus (ppm) & 143.0 & 23.21 & 98.45 \\
\hline Silicate-silica (ppm) & 7.1 & 0.52 & 2.19 \\
\hline
\end{tabular}

Table 2: Descriptive statistics of water quality parameters of Kole 


\begin{tabular}{|llll|}
\hline Parameters & Mean & SE & SD \\
\hline Transparency $(\mathrm{m})$ & 1.2 & 0.1 & 0.3 \\
\hline Water coverage(\%) & 0.6 & 0.04 & 0.2 \\
\hline Macrophyte coverage (\%) & 0.4 & 0.03 & 0.1 \\
\hline Depth(m) & 60.9 & 2.3 & 9.8 \\
\hline Temp (Air) ${ }^{\circ} \mathrm{C}$ & 34.9 & 2.6 & 11.0 \\
\hline Temp (Water) ${ }^{\circ} \mathrm{C}$ & 0.02 & 0.001 & 0.004 \\
\hline Water reaction(pH) & 67.8 & 3.2 & 13.7 \\
\hline Specific conductivity $(\mu \mathrm{S} / \mathrm{cm})$ & 16.2 & 1.2 & 5.0 \\
\hline Dissolved oxygen (ppm) & 2.2 & 0.1 & 0.5 \\
\hline Free Carbon di Oxide (ppm) & 27.5 & 1.1 & 4.6 \\
\hline Total Alkalinity (ppm) & 26.6 & 1.0 & 4.4 \\
\hline Total Hardness (ppm) & 7.9 & 0.1 & 0.2 \\
\hline Calcium (ppm) & 472.3 & 11.0 & 46.5 \\
\hline Magnesium(ppm) & 7.7 & 0.1 & 0.5 \\
\hline Chloride (ppm) & 1.3 & 0.3 & 1.3 \\
\hline Nitrate - N (ppm) & 145.2 & 2.5 & 10.5 \\
\hline Phosphate-phophorus (ppm) & 149.6 & 2.4 & 10.3 \\
\hline Silicate-silica (ppm) & 34.8 & 1.1 & 4.7 \\
\hline
\end{tabular}

Table 3: Diversity of phytoplankton in selected beels (floodplain wetlands) of west Bengal 


\begin{tabular}{|c|c|}
\hline Myxophyceae & Pandorina morum $(\mathrm{S}, \mathrm{K})$ \\
\hline Anabaena spiroides $(\mathrm{S}, \mathrm{K})$ & Pediastrum duplex $(\mathrm{S}, \mathrm{K})$ \\
\hline Aphanocapsa roeseana $(\mathrm{S}, \mathrm{K})$ & Scenedesmus obliqumus (S,K) \\
\hline Aphanothece pallida $(\mathrm{S}, \mathrm{K})$ & Spirogyra maxima $(\mathrm{S}, \mathrm{K})$ \\
\hline Chroococcus minutus $(\mathrm{S}, \mathrm{K})$ & Staurasterum orbiculare (S) \\
\hline Cylindrospermum sp (S,K) & Stigoclonium $s p(\mathrm{~S}, \mathrm{~K})$ \\
\hline Gleocapsa $s p(\mathrm{~S}, \mathrm{~K})$ & Tetraedon sp (SK) \\
\hline Gloeotrichia echinulat (S,K) & Tetraspora gelatinosa $(S)$ \\
\hline Lyngbya birgei $(\mathrm{S}, \mathrm{K})$ & Ulothrix zonata $(\mathrm{S}, \mathrm{K})$ \\
\hline Merismopedia minima $(\mathrm{S}, \mathrm{K})$ & Westella botryoides $(K)$ \\
\hline Microcystis aeruginosa $(\mathrm{S}, \mathrm{K})$ & Volvox areus $(\mathrm{S}, \mathrm{K})$ \\
\hline Nostoc linckia $(\mathrm{S}, \mathrm{K})$ & Bacillariophyceae \\
\hline Oscillatoria rubescens $(\mathrm{S}, \mathrm{K})$ & Amphora coffeaeformis $(\mathrm{S}, \mathrm{K})$ \\
\hline Phormidium inundatum $(\mathrm{S}, \mathrm{K})$ & Cyclotella meneginiyana $(\mathrm{S}, \mathrm{K})$ \\
\hline Rivullaria aquatica (K) & Cymbella lanceolata (S) \\
\hline Spirulina princeps $(\mathrm{S}, \mathrm{K})$ & Eunotia pectinalis $(S)$ \\
\hline Actinasrtum gracillinum $(\mathrm{S}, \mathrm{K})$ & Fragillaria brevistriata $(S)$ \\
\hline Eudorina elegans $(\mathrm{S}, \mathrm{K})$ & Gomphonema lanceolatum (S,K) \\
\hline Ankistrodesmus falcatus (S,K) & Gyrosigma acuminatum (S,K) \\
\hline Asterococcus limneticus (S, K) & Melosira granulate $(\mathrm{S}, \mathrm{K})$ \\
\hline Characium augustum $(\mathrm{K})$ & Navicula radiosa $(\mathrm{S}, \mathrm{K})$ \\
\hline Chlorella vulgaris $(\mathrm{S}, \mathrm{K})$ & Nitzschia sigmoidia (S,K) \\
\hline Chlorococcum infusionum (S) & Pinnularia major $(\mathrm{S}, \mathrm{K})$ \\
\hline Cladophora $s p(\mathrm{~S}, \mathrm{~K})$ & Rhopalodia gibba (S,K) \\
\hline Closterium parvulum $(\mathrm{S}, \mathrm{K})$ & Surirella $s p(\mathrm{~S}, \mathrm{~K})$ \\
\hline Cosmerium bengalicum (S,K) & Synedra capitata (S,K) \\
\hline Crucigenia quadrata (S,K) & Euglenophyceae \\
\hline Dictyosphaerium pulchellum (S) & Euglena viridis $(S)$ \\
\hline Euastrum spinulosum $(\mathrm{S}, \mathrm{K})$ & Phacus caudate $(\mathrm{S}, \mathrm{K})$ \\
\hline
\end{tabular}




\begin{tabular}{|ll|} 
Hydrodiction idium $(\mathrm{S}, \mathrm{K})$ & Dinophyceae \\
\hline Micrasterius agardh $(\mathrm{S}, \mathrm{K})$ & Ceratium macroceros $(\mathrm{S})$ \\
\hline Mougeotia genuflexa $(\mathrm{S}, \mathrm{K})$ & Xanthophyceae \\
\hline Oedogonium australe $(\mathrm{S}, \mathrm{K})$ & Botrydium granulatum $(\mathrm{S}, \mathrm{K})$ \\
\hline Oocystis crassa $(\mathrm{S})$ & Tribonema vulgare $(\mathrm{K})$ \\
\hline
\end{tabular}

S=Saguna Floodplain wetland, K= Kole Floodplain wetland

Table 4: Descriptive statistics of Phytoplankton data of Saguna

\begin{tabular}{|lllll|}
\hline SI. No. & Parameters & Mean & SE & SD \\
\hline 1. & Total Plankton NO & 1849.6 & 92.36 & 391.85 \\
\hline 2. & Phytoplankton No & 1543.2 & 75.90 & 322.01 \\
\hline 3. & Myxophyceae No & 404.5 & 28.23 & 119.75 \\
\hline 4. & Chlorophyceae No & 355.1 & 44.29 & 187.89 \\
\hline 5. & Bacillariophyceae No & 529.8 & 20.22 & 85.80 \\
\hline 6. & Euglenoida No & 131.4 & 12.91 & 54.78 \\
\hline 7. & Dinophyceae No & 83.6 & 9.64 & 40.88 \\
\hline 8. & Xanthophyceae No & 38.8 & 5.67 & 24.04 \\
\hline
\end{tabular}

Table 5: Descriptive statistics of Phytoplankton data of Kole

\begin{tabular}{|lllll|}
\hline SI. No. & Parameters & Mean & SE & SD \\
\hline 1. & Total Plankton NO & 1111.8 & 56.4 & 239.3 \\
\hline 2. & Phytoplankton No & 1052.0 & 60.4 & 256.1 \\
\hline 3. & Myxophyceae No & 295.7 & 23.5 & 99.8 \\
\hline 4. & Chlorophyceae No & 243.7 & 28.2 & 119.6 \\
\hline 5. & Bacillariophyceae No & 316.5 & 26.0 & 110.3 \\
\hline 6. & Euglenoida No & 93.6 & 9.7 & 41.3 \\
\hline 7. & Dinophyceae No & 78.6 & 9.9 & 42.1 \\
\hline 8. & Xanthophyceae No & 23.9 & 4.3 & 18.1 \\
\hline
\end{tabular}


Table 6: Diversity of zooplankton in selected beels (floodplain wetlands) of west Bengal

\begin{tabular}{|lll|}
\hline Zooplankton & & \\
\hline Copepod & Rotifer & Protozoa \\
\hline Nauplii larvae $(\mathrm{S}, \mathrm{K})$ & Asplanchna intaonedia $(\mathrm{S}, \mathrm{K})$ & Arcella discoides $(\mathrm{S}, \mathrm{K})$ \\
\hline Cyclops larvae $(\mathrm{S}, \mathrm{K})$ & Brachionus caudatus $(\mathrm{S}, \mathrm{K})$ & Centropyxis aculeata $(\mathrm{S}, \mathrm{K})$ \\
\hline Cladocera & Filinia longiseta $(\mathrm{S}, \mathrm{K})$ & Difflugia rubsence $(\mathrm{S})$ \\
\hline Daphnia pulex $(\mathrm{S}, \mathrm{K})$ & Keratella tropica $(\mathrm{S}, \mathrm{K})$ & Vorticella sp $(\mathrm{S})$ \\
\hline Ceriodaphnia rigaudi $(\mathrm{S}, \mathrm{K})$ & Lecane paxiana $(\mathrm{S}, \mathrm{K})$ & \\
\hline Moina brachiata $(\mathrm{S}, \mathrm{K})$ & Monostylla closterocera $(\mathrm{S}, \mathrm{K})$ & \\
\hline Bosmina longirostris $(\mathrm{S}, \mathrm{K})$ & Nathalca $s p(\mathrm{~S}, \mathrm{~K})$ & \\
\hline & Polyarthra $s p(\mathrm{~S}, \mathrm{~K})$ & \\
\hline & Platysis $s p(\mathrm{~S}, \mathrm{~K})$ & \\
\hline
\end{tabular}

$\mathrm{S}=$ Saguna Floodplain wetland, $\mathrm{K}=$ Kole Floodplain wetland

Table 7: Descriptive statistics of Zooplankton data of Saguna

\begin{tabular}{|llll|}
\hline Parameters & Mean & SE & SD \\
\hline ZPNO & 310.4 & 30.78 & 130.59 \\
\hline COPNO & 103.6 & 11.83 & 50.17 \\
\hline ROTNO & 105.2 & 12.27 & 52.04 \\
\hline CLADONO & 53.3 & 6.97 & 29.59 \\
\hline PROTONO & 32.8 & 4.56 & 29.00 \\
\hline MISCNO & 15.8 & 1.95 & 8.29 \\
\hline
\end{tabular}

Table 8: Descriptive statistics of Zooplankton data of Kole 


\begin{tabular}{|llll|}
\hline Parameters & Mean & SE & SD \\
\hline ZPNO & 82.8 & 4.8 & 20.4 \\
\hline COPNO & 31.9 & 3.3 & 14.2 \\
\hline ROTNO & 19.7 & 1.1 & 4.9 \\
\hline CLADONO & 17.1 & 1.6 & 7.0 \\
\hline PROTONO & 9.1 & 0.9 & 3.7 \\
\hline MISCNO & 5.0 & 0.6 & 2.4 \\
\hline
\end{tabular}

Table 9: Diversity of periphyton in selected beels (floodplain lakes) of West Bengal, (2011-13) 


\begin{tabular}{|c|c|c|c|}
\hline SI. No. & Myxophyceae & SI. No. & Bacillariophyceae \\
\hline 1 & Anabaena spiroides $(\mathrm{S}, \mathrm{K})$ & 24 & Amphora coffeaeformis $(\mathrm{S}, \mathrm{K})$ \\
\hline 2 & Aphanocapsa crassa $(\mathrm{S}, \mathrm{K})$ & 25 & Closterum parvulum $(\mathrm{S}, \mathrm{K})$ \\
\hline 3 & Chroococcus minutus $(\mathrm{S}, \mathrm{K})$ & 26 & Cosmarium bengalicum $(\mathrm{S}, \mathrm{K})$ \\
\hline 4 & Cylindrospermum muscicola $(\mathrm{S}, \mathrm{K})$ & 27 & Cyclotella meneginiyana $(\mathrm{S}, \mathrm{K})$ \\
\hline 5 & Gleocapsa $s p(\mathrm{~S}, \mathrm{~K})$ & 28 & Cymbella lanceolata $(\mathrm{S}, \mathrm{K})$ \\
\hline 6 & Gleotrichia echinulat $(\mathrm{S}, \mathrm{K})$ & 29 & Diatoma $s p(\mathrm{~S}, \mathrm{~K})$ \\
\hline 7 & Lyngbya birgei (S,K) & 30 & Diploneis ovalis $(\mathrm{S}, \mathrm{K})$ \\
\hline 8 & Merismopedia minima $(\mathrm{S}, \mathrm{K})$ & 31 & Gomphonema lanceolatum $(\mathrm{S}, \mathrm{K})$ \\
\hline 9 & Nostoc linckia $(\mathrm{S}, \mathrm{K})$ & 32 & Gyrosigma acuminatum (S,K) \\
\hline 10 & Oscillatoria rubescens $(\mathrm{S}, \mathrm{K})$ & 33 & Melosira granulate(SK) \\
\hline \multirow[t]{2}{*}{11} & Phormidium inundatum (S,K) & 34 & Navicula radiosa $(\mathrm{S}, \mathrm{K})$ \\
\hline & Chlorophyceae & 35 & Nitzschia sigmoidia (S,K) \\
\hline 12 & Chlorella vulgaris $(\mathrm{S}, \mathrm{K})$ & 36 & Pinnularia major $(\mathrm{S}, \mathrm{K})$ \\
\hline 13 & Closteridium difficile $(\mathrm{S}, \mathrm{K})$ & 37 & Rhopalodia gibba $(\mathrm{S}, \mathrm{K})$ \\
\hline 14 & Crucigenia quadrata $(\mathrm{S}, \mathrm{K})$ & 38 & Synedra capitata (S,K) \\
\hline 15 & Mougeotia genuflexa $(\mathrm{S}, \mathrm{K})$ & 39 & Euglena viridis $(\mathrm{S}, \mathrm{K})$ \\
\hline 16 & Oedogonium australe $(\mathrm{S}, \mathrm{K})$ & 40 & Phacus caudate $(\mathrm{S}, \mathrm{K})$ \\
\hline 17 & Pediastrum duplex $(\mathrm{S}, \mathrm{K})$ & 41 & Tribonema vulgare $(\mathrm{S}, \mathrm{K})$ \\
\hline 18 & Scenedesmus obliqumus (S,K) & 42 & Dinobryon divergens $(\mathrm{S}, \mathrm{K})$ \\
\hline 19 & Spirogyra maxima $(\mathrm{S}, \mathrm{K})$ & & Animalcules \\
\hline 20 & Staurastrum orbiculare $(S)$ & 43 & Difflugia humilis $(\mathrm{S}, \mathrm{K})$ \\
\hline 21 & Tetraedon $s p(\mathrm{~S}, \mathrm{~K})$ & 44 & Actinospherium $s p(\mathrm{~S}, \mathrm{~K})$ \\
\hline 22 & Ulothrix zonata $(\mathrm{S}, \mathrm{K})$ & 45 & Conochilus unicornis $(\mathrm{S}, \mathrm{K})$ \\
\hline \multirow[t]{2}{*}{23} & Zygnema sp $(\mathrm{S}, \mathrm{K})$ & 46 & Brachionus falcatus $(\mathrm{S}, \mathrm{K})$ \\
\hline & & 47 & Keratella tropica $(\mathrm{S}, \mathrm{K})$ \\
\hline
\end{tabular}

S=Saguna Floodplain wetland, K= Kole Floodplain wetland

Table 10: Descriptive statistics of Periphyton data of Saguna 


\begin{tabular}{|llll|}
\hline Parameters & Mean & SE & SD \\
\hline PERITOT & 434.4 & 37.88 & 160.70 \\
\hline PMYXONo & 99.0 & 8.10 & 34.38 \\
\hline PCHLORONo & 87.6 & 5.78 & 24.54 \\
\hline BACILNO1 & 139.1 & 14.61 & 61.98 \\
\hline PMISCNO & 108.9 & 13.52 & 57.37 \\
\hline
\end{tabular}

Table 11: Descriptive statistics of Periphyton data of Kole

\begin{tabular}{|llll|}
\hline Parameters & Mean & SE & SD \\
\hline PERITOT & 550.5 & 51.2 & 217.2 \\
\hline PMYXONo & 189.4 & 23.3 & 98.8 \\
\hline PCHLORONo & 106.5 & 6.3 & 26.7 \\
\hline BACILNo1 & 158.2 & 18.9 & 80.3 \\
\hline PMISCNO & 96.4 & 5.7 & 24.0 \\
\hline
\end{tabular}

Table 12: Diversity of macrophytes in selected beels (floodplain wetlands) of West Bengal 


\begin{tabular}{|c|c|c|c|}
\hline Macrophyte & Family & Occurance & $\%$ \\
\hline Floating & & & $50-60$ \\
\hline Eichhornia crasipes $(S, K)$ & Pontederiaceae & Floating & \\
\hline Azolla pinnata $(S, K)$ & Azollaceae & Floating & \\
\hline Pistia stratiotes $(S, K)$ & Araceae & Floating & \\
\hline Lemna minor(S,K) & Lemnaceae & Floating & \\
\hline Lemna perpusilla (S) & Lemnaceae & Floating & \\
\hline Spirodella polyrhiza (S) & Lemnaceae & Floating & \\
\hline Wolfia arhiza $(S, K)$ & Lemnaceae & Floating & \\
\hline Trapa natans $(S, K)$ & Trapaceae & Floating & \\
\hline Rooted floating & & Floating & \\
\hline Nymphoides indicum $(S, K)$ & Gentianaceae & Floating & \\
\hline Nelumbo nucifera $(S, K)$ & $\begin{array}{l}\text { Brassicaceae } \\
\text { (Cruciferae) }\end{array}$ & Floating & \\
\hline Nymphaea stellate $(S, K)$ & Nymphaeaceae & Floating & \\
\hline Nymphaea nauchali $(S, K)$ & Nymphaeaceae & Floating & \\
\hline Euryale ferox $(S, K)$ & Nymphaeaceae & Floating & \\
\hline Potamogeton nodosus $(S, K)$ & Potamogetonaceae & Floating & \\
\hline $\begin{array}{l}\text { Myriophylum tuberculatum } \\
(S, K)\end{array}$ & Haloragaceae & Floating & \\
\hline Aponogeton natans $(S, K)$ & Aponogetonaceae & Floating & \\
\hline Submerged & & & $15-20$ \\
\hline Hydrilla verticillata $(S, K)$ & Hydrocharitaceae & Submerged & \\
\hline Ceratophyllum demersum $(S, K)$ & Ceratophyllaceae & Submerged & \\
\hline Vallisneria spiralis $(S, K)$ & Hydrocharitaceae & Submerged & \\
\hline Potamogeton pectinatus $(S, K)$ & Potamogetonaceae & Submerged & \\
\hline Najas minor $(S, K)$ & Hydrocharitaceae & Submerged & \\
\hline Chara vulgaris $(S)$ & Characeae & Submerged & \\
\hline Chara zeylanica $(S, K)$ & Characeae & Submerged & \\
\hline Chara nuda $(S, K)$ & Characeae & Submerged & \\
\hline
\end{tabular}




\begin{tabular}{|c|c|c|c|}
\hline \multicolumn{3}{|c|}{ Marginal (prostrate emergent) } & $10-15$ \\
\hline Marselia quadrifolia $(S, K)$ & Marseliaceae & $\begin{array}{l}\text { Marginal(prostrate } \\
\text { emergent) }\end{array}$ & \\
\hline Marselia minuta $(S)$ & Marseliaceae & $\begin{array}{l}\text { Marginal(prostrate } \\
\text { emergent) }\end{array}$ & \\
\hline Ipomoea aquatic $(S, K)$ & Convolvulaceae ${ }^{-}$ & $\begin{array}{l}\text { Marginal(prostrate } \\
\text { emergent) }\end{array}$ & \\
\hline Enhydra fuctuans(S) & Compositae & $\begin{array}{l}\text { Marginal(prostrate } \\
\text { emergent) }\end{array}$ & \\
\hline Marginal (erect element) & & & $1-5$ \\
\hline Acorus calamus (S) & Acoraceae & Marginal (erect element) & \\
\hline Colocasia esculenta $(S, K)$ & Araceae & Marginal (erect element) & \\
\hline Cyperus difformis $(S, K)$ & Cyperaceae & Marginal (erect element) & \\
\hline Cyperus procerus $(S, K)$ & Cyperaceae & Marginal (erect element) & \\
\hline Limnophyla indica $(S, K)$ & Scrophulariaceae & Marginal (erect element) & \\
\hline
\end{tabular}

$\mathrm{S}=$ Saguna Floodplain wetland, $\mathrm{K}=$ Kole Floodplain wetland

Table 13: Diversity of Macrobenthic Invertebrate in selected floodplain wetlands of west Bengal 


\begin{tabular}{|llll|}
\hline SI. No. & Gastropods & Sl. No. & Bivalve \\
\hline 1. & Planorbis compressus $(S, K)$ & 16 & Aelosoma bengalensis $(S, K)$ \\
\hline 2. & Vivipora bengalenis $(S, K)$ & 17 & Nais simplex $(S, K)$ \\
\hline 3. & Pila globosa $(S, K)$ & 18. & Nais pectinata $(S)$ \\
\hline 4. & Bellamya bengalensis $(S, K)$ & 19 & Limnodrilus hoffmeisteri $(S, K)$ \\
\hline 5. & Digniostemma pulchella $(S, K)$ & 20 & Tubifex tubifex $(S, K)$ \\
\hline 6. & Lymnea acuminate $(S, K)$ & 21 & Chaetogastor orientalis $(S, K)$ \\
\hline 7. & Indoplanorbis exustus $(S, K)$ & & Chironomid \\
\hline 8. & Gobia orcula $(S, K)$ & 22 & Chironomus $s p(S, K)$ \\
\hline 9. & Orbicular striatella $(S, K)$ & & Miscellaneous organism \\
\hline 10. & Gyraulus convexiusculus $(S, K)$ & 23 & Hellobdella triserialis $(S)$ \\
\hline 11. & Thiara acuminate $(S)$ & 24 & Nymphs of dragon $f l y(S, K)$ \\
\hline & Bivalve & 25 & Damsel fly $(S, K)$ \\
\hline 12. & Lamellidens marginalis $(S)$ & 26 & Stone fly $(S, K)$ \\
\hline 13 & Unio tumidus $(S, K)$ & 27 & May fly $(S, K)$ \\
\hline 14. & Parreysia fevidens-plagiasoma $(S, K)$ & 28 & Eeucypris affinis $(S, K)$ \\
\hline 15. & Parreysia radiatula caerulea $(S, K)$ & 29 & Stenocypris sp. $(S, K)$ \\
\hline & & & \\
\hline
\end{tabular}

S=Saguna Floodplain wetland, $K=$ Kole Floodplain wetland

Table 14: Descriptive statistics of Benthos data of Saguna

\begin{tabular}{|llll|}
\hline Parameters & Mean & SE & SD \\
\hline Benthos (Total No) & 336.9 & 26.17 & 111.01 \\
\hline Gastropod No & 290.3 & 27.43 & 116.39 \\
\hline Bivalve No & 12.9 & 2.25 & 9.53 \\
\hline Oligochaete No & 17.6 & 4.13 & 17.52 \\
\hline Chironomids No & 10.2 & 2.69 & 11.40 \\
\hline Other No & 5.9 & 0.86 & 3.67 \\
\hline
\end{tabular}

Table 15: Descriptive statistics of Benthos data of Kole 


\begin{tabular}{|llll|}
\hline Parameters & Mean & SE & SD \\
\hline Benthos (Total No) & 383.6 & 29.2 & 124.1 \\
\hline Gastropod No & 317.1 & 28.9 & 122.8 \\
\hline Bivalve No & 16.5 & 2.3 & 9.6 \\
\hline Oligochaete No & 21.2 & 4.5 & 19.2 \\
\hline Chironomids No & 15.3 & 3.8 & 16.1 \\
\hline Other No & 13.5 & 1.2 & 4.9 \\
\hline
\end{tabular}

Table 16: Descriptive statistics of Productivity data of Saguna

\begin{tabular}{|llll|}
\hline Parameters & Mean & SE & SD \\
\hline Gross Primary Productivity & 0.5 & 0.04 & 0.15 \\
\hline Net Primary Productivity & 0.3 & 0.03 & 0.12 \\
\hline Assimilation efficiency & 57.8 & 1.74 & 7.37 \\
\hline Respiration & 28.1 & 1.52 & 6.43 \\
\hline Photosynthesis Respiration Ratio & 0.0 & 0.00 & 0.00 \\
\hline
\end{tabular}

Table 17: Descriptive statistics of Productivity data of Kole

\begin{tabular}{|llll|}
\hline Parameters & Mean & SE & SD \\
\hline Gross Primary Productivity & 0.6 & 0.0 & 0.2 \\
\hline Net Primary Productivity & 0.4 & 0.0 & 0.1 \\
\hline Assimilation efficiency & 60.9 & 2.3 & 9.8 \\
\hline Respiration & 34.9 & 2.6 & 11.0 \\
\hline Photosynthesis Respiration Ratio & 0.0 & 0.0 & 0.0 \\
\hline
\end{tabular}

\section{Figures}




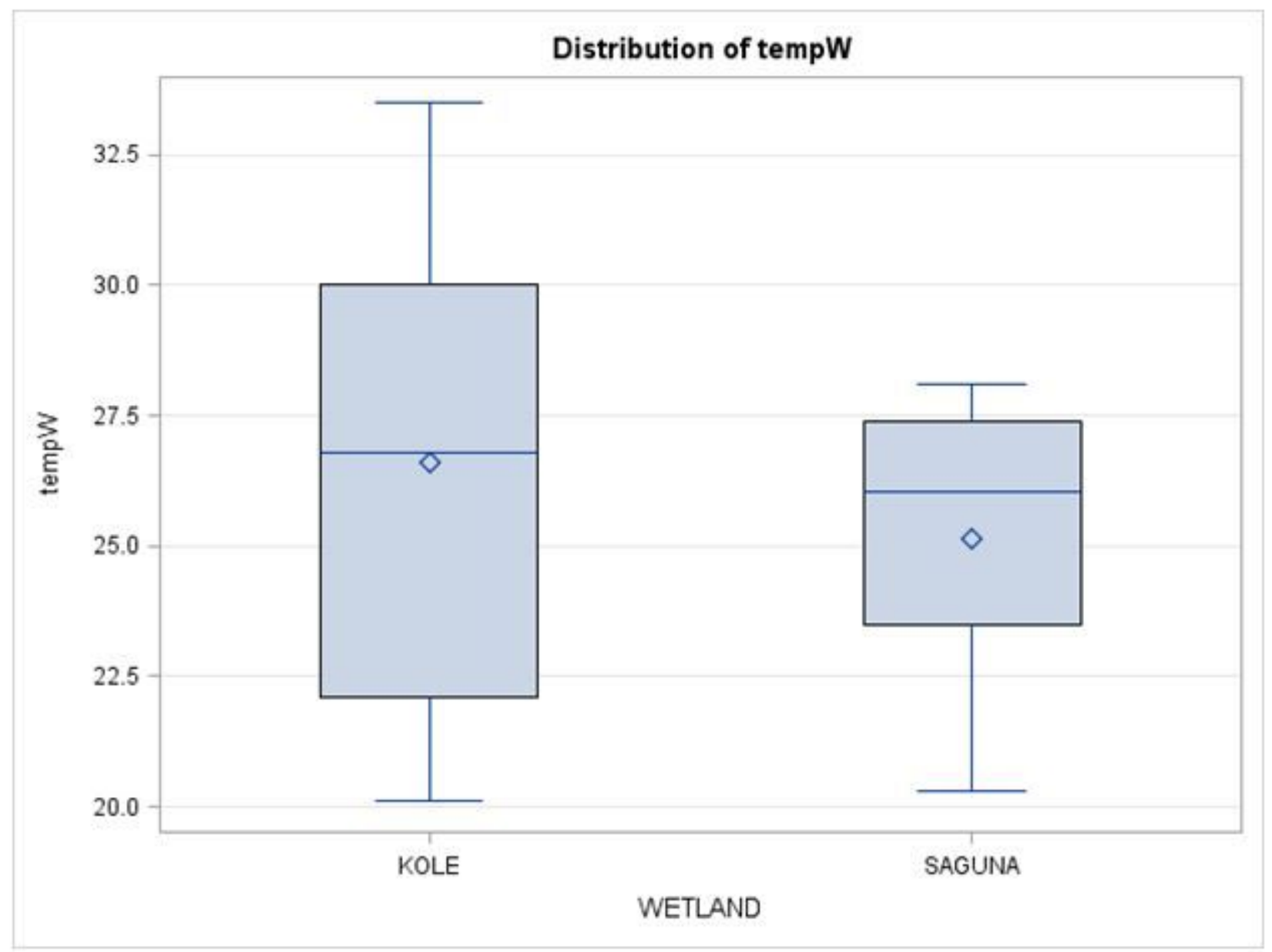

Figure 1

Boxplot for water temp of the selected floodplain wetlands 

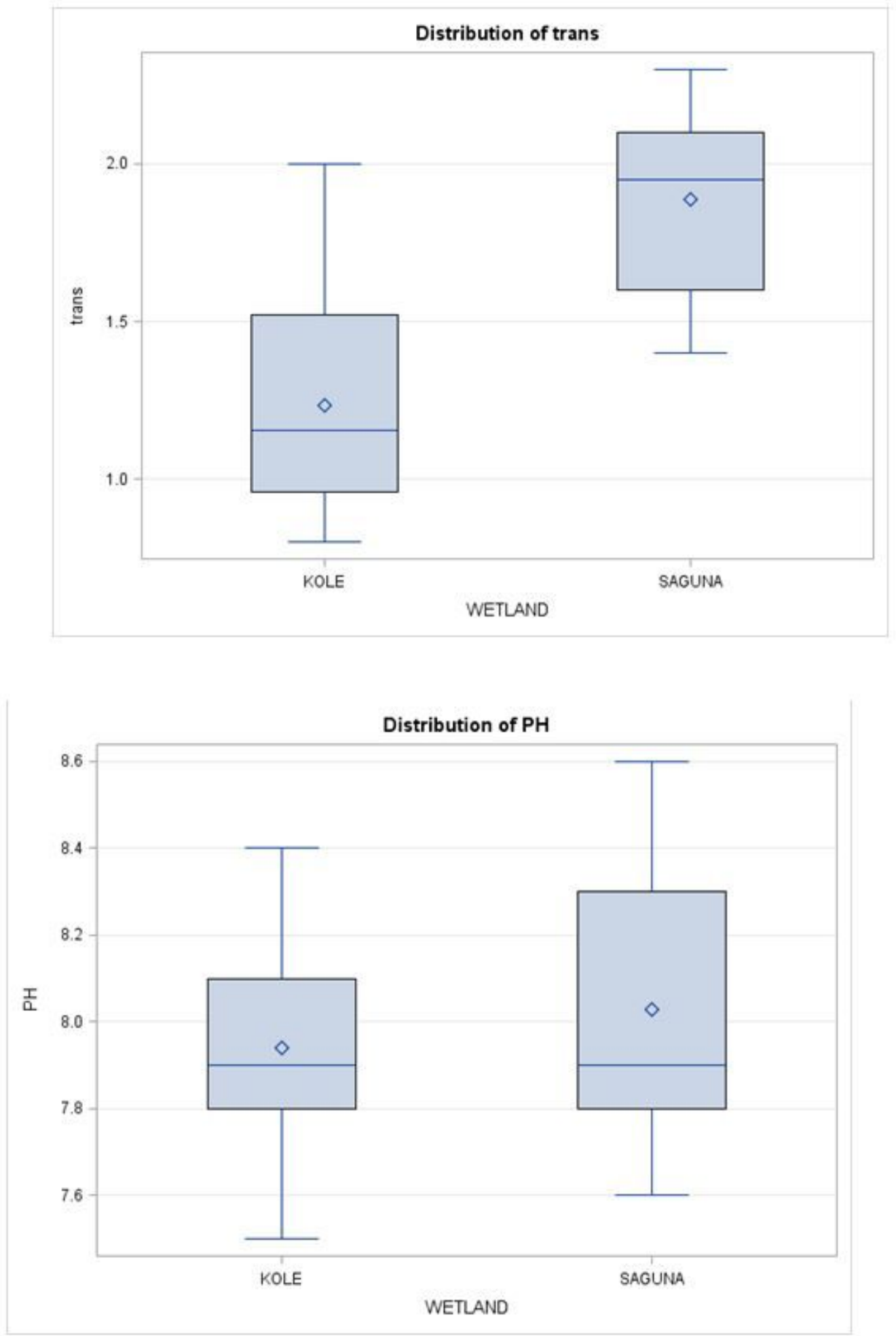

\section{Figure 2}

2a: Boxplot for transparency of the selected floodplain wetlands $2 \mathrm{~b}$ : Boxplot for $\mathrm{pH}$ of the selected floodplain wetlands 

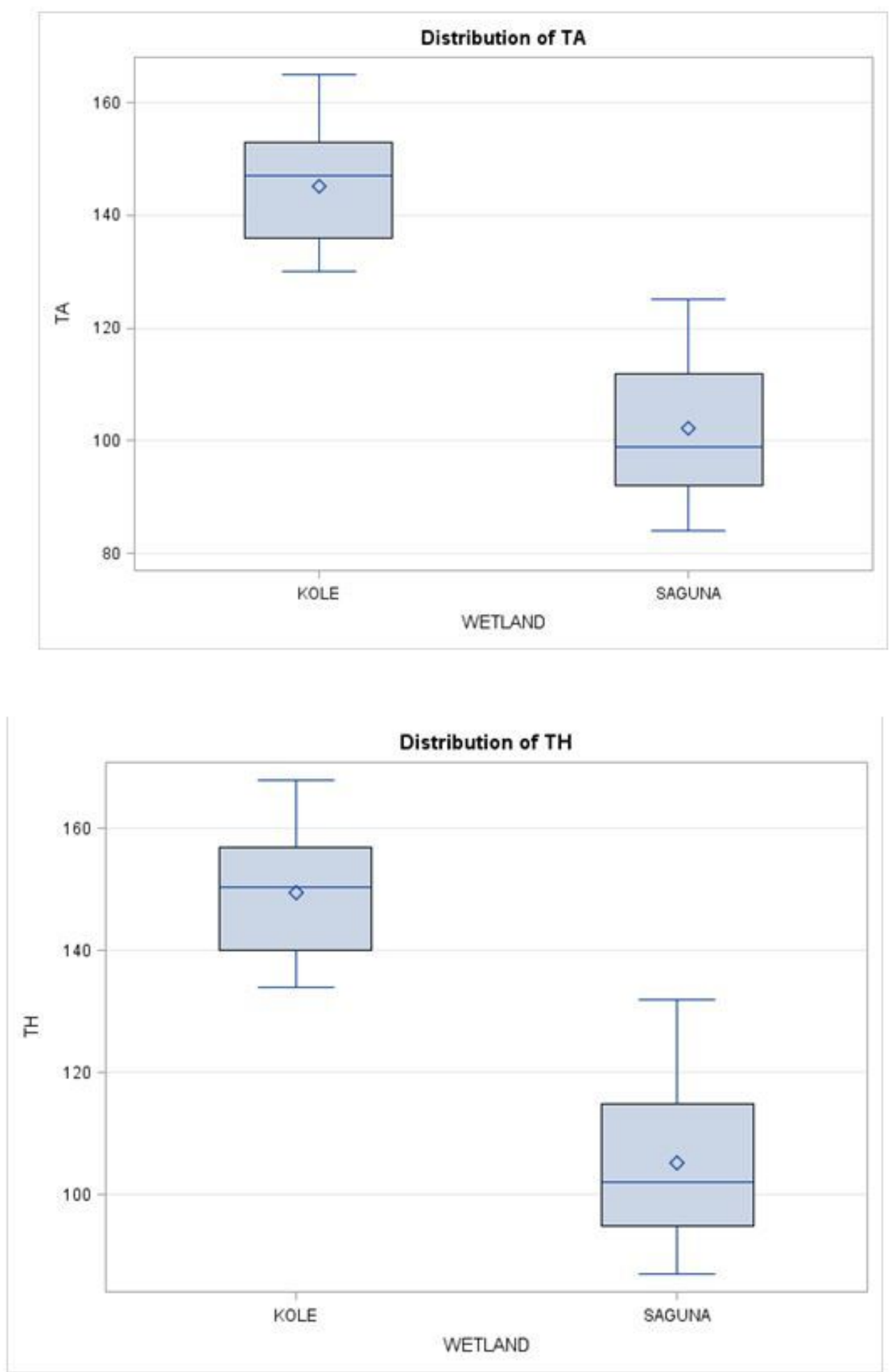

\section{Figure 3}

3a: Boxplot for Total alkalinity of the selected floodplain wetlands 3b: Boxplot for total hardness of the selected floodplain wetlands 

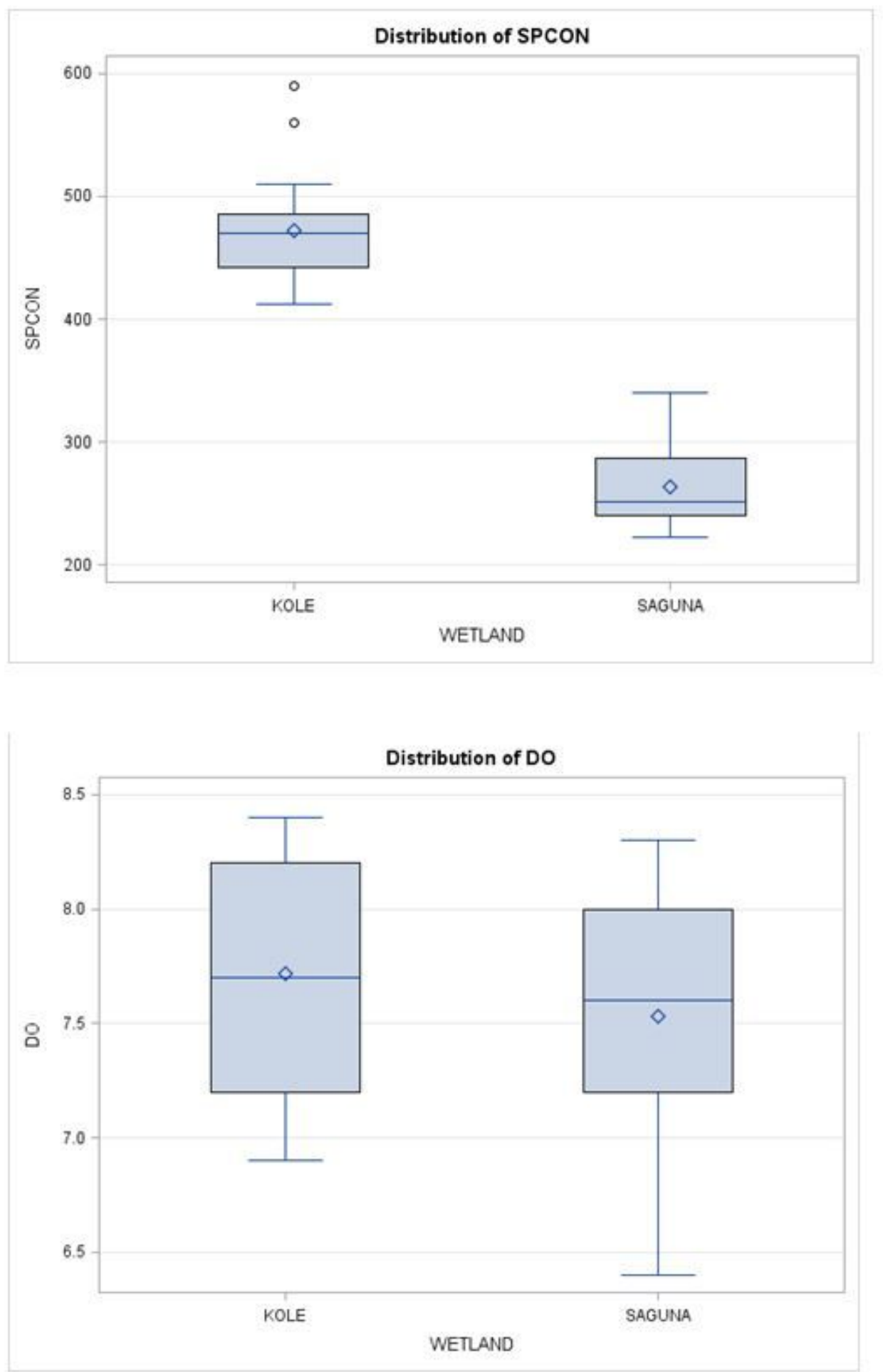

\section{Figure 4}

4a: Boxplot for Specific conductivity of the selected floodplain wetlands 4b: Boxplot for Dissolved oxygen of the selected floodplain wetlands 

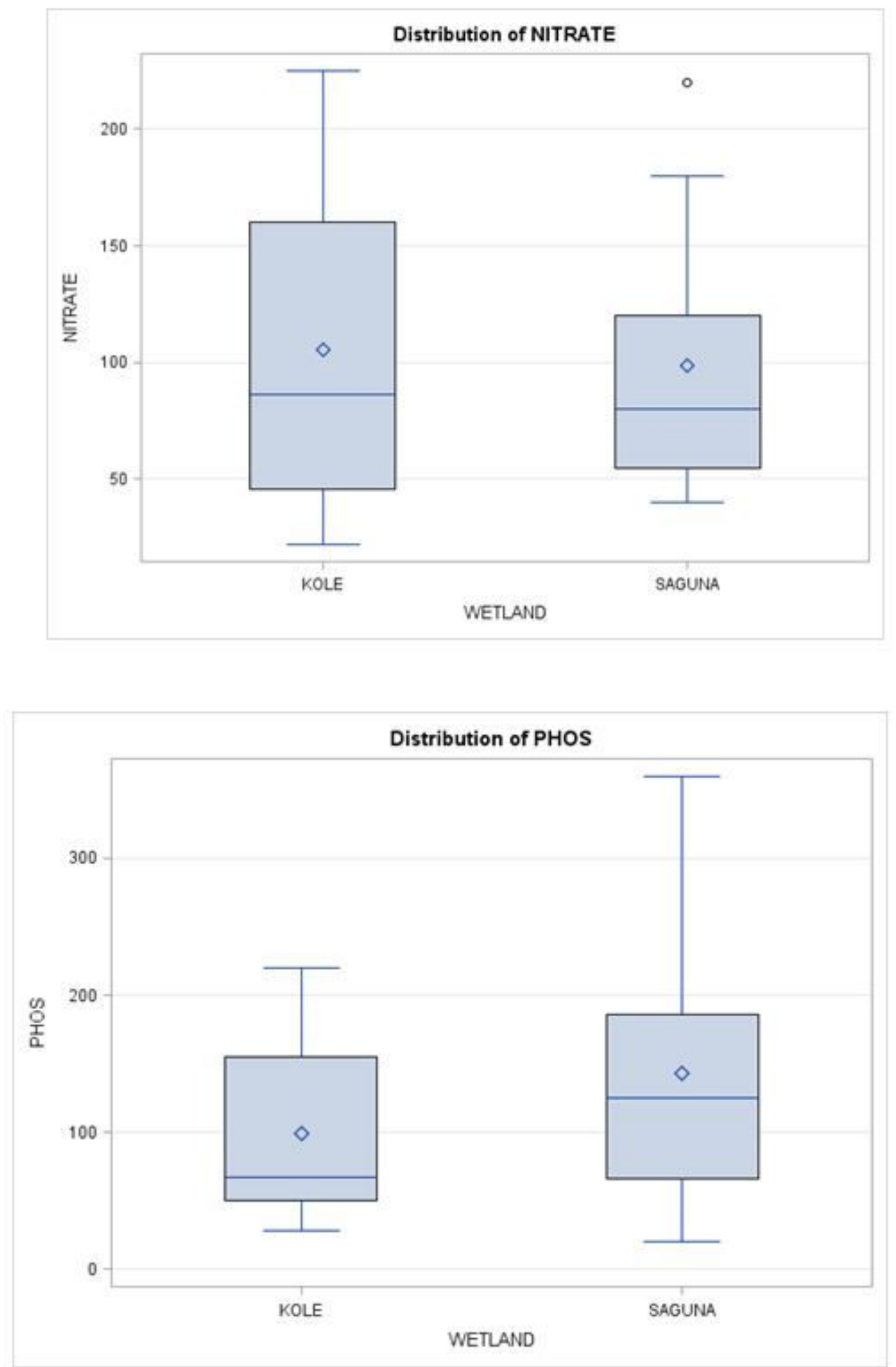

\section{Figure 5}

5a: Boxplot for Nitrate-Nitrogen of the selected floodplain wetlands 5b: Boxplot for phosphatephosphorous of the selected floodplain wetlands 

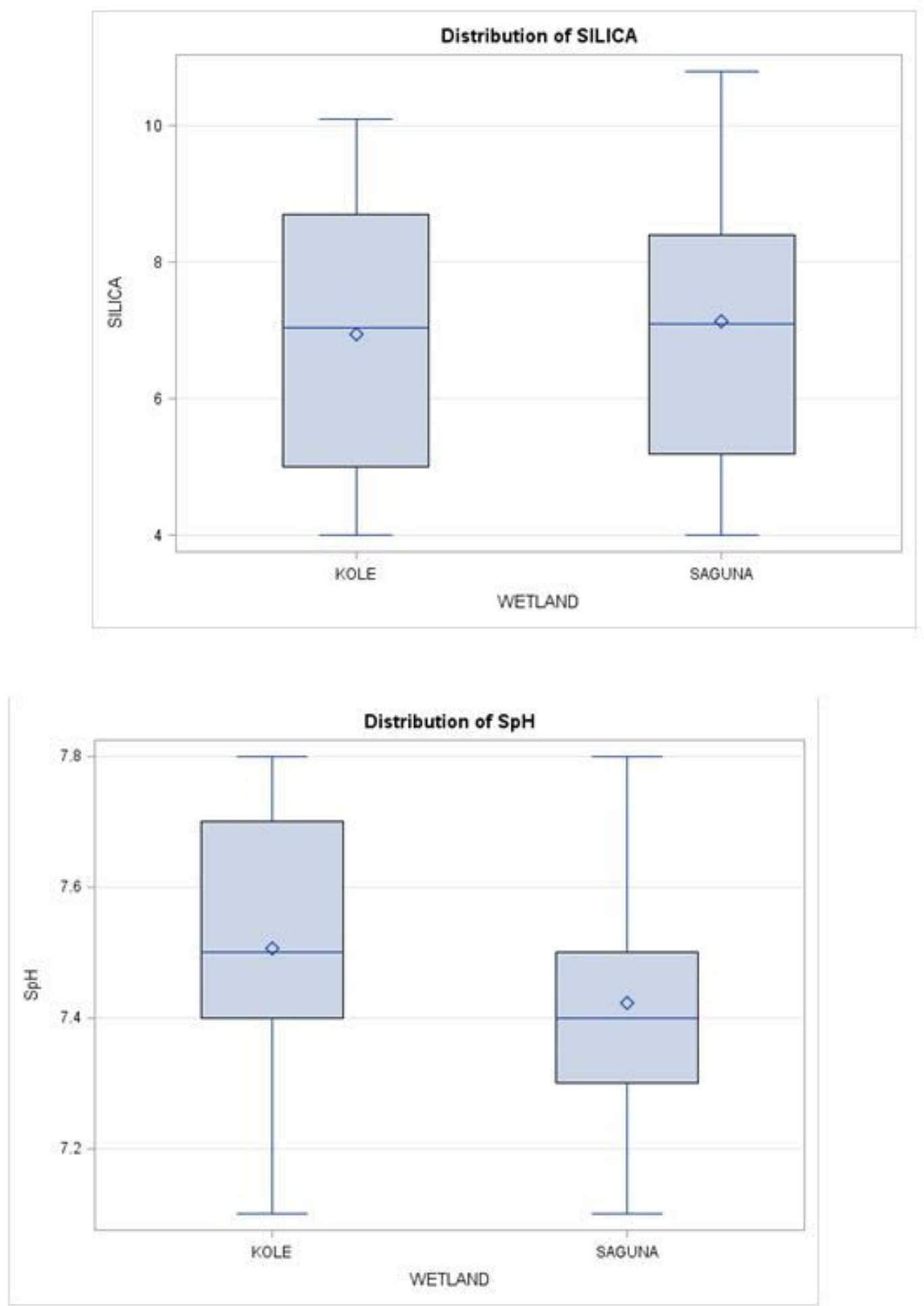

\section{Figure 6}

6a: Boxplot for silicate-Silica of the selected floodplain wetlands $6 \mathrm{~b}$ : Boxplot for soil pH of the selected floodplain wetlands 

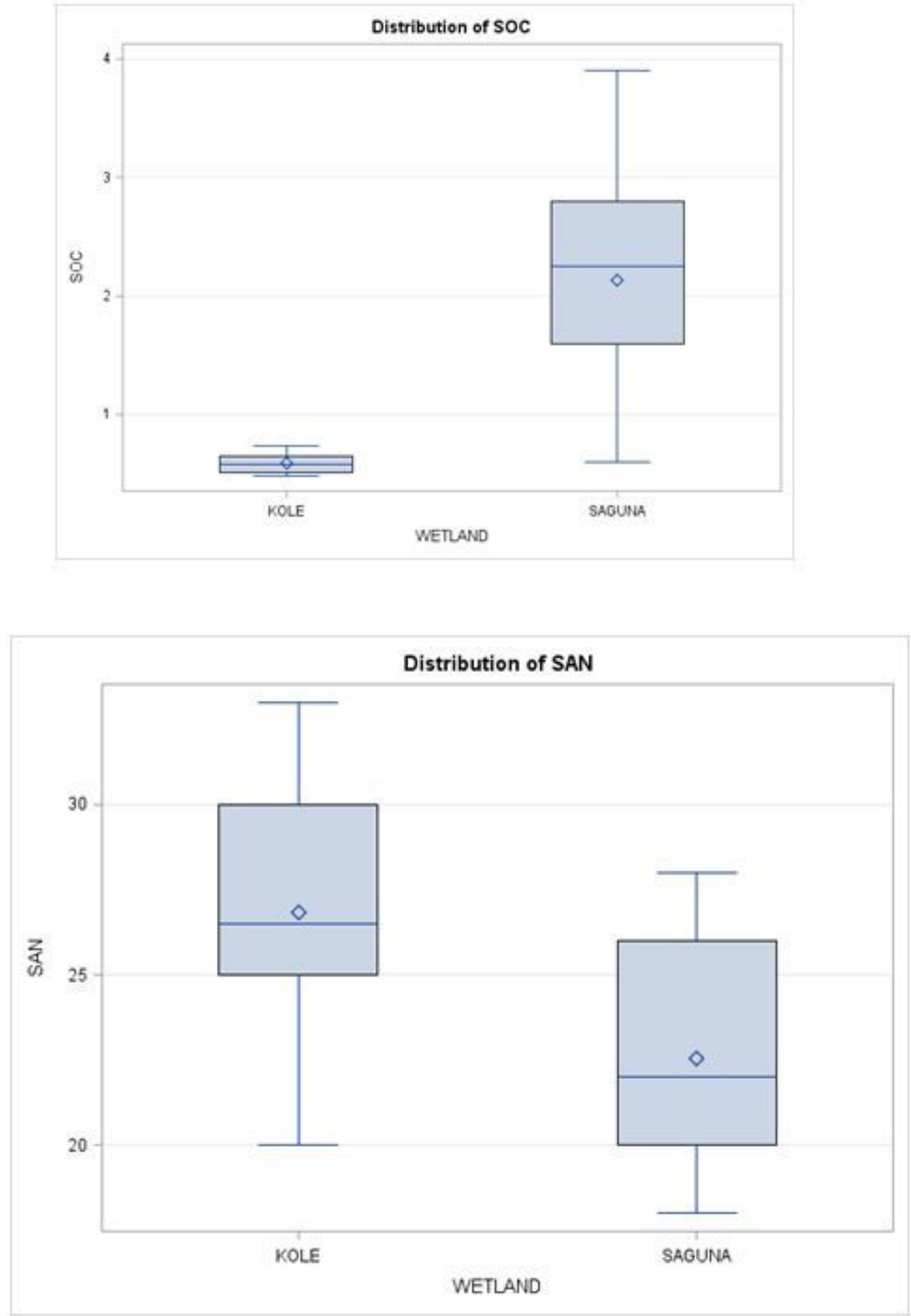

Figure 7

7a: Boxplot for organic carbon of soil of the selected floodplain wetlands 7b: Boxplot for Available nitrogen of the selected floodplain wetlands 

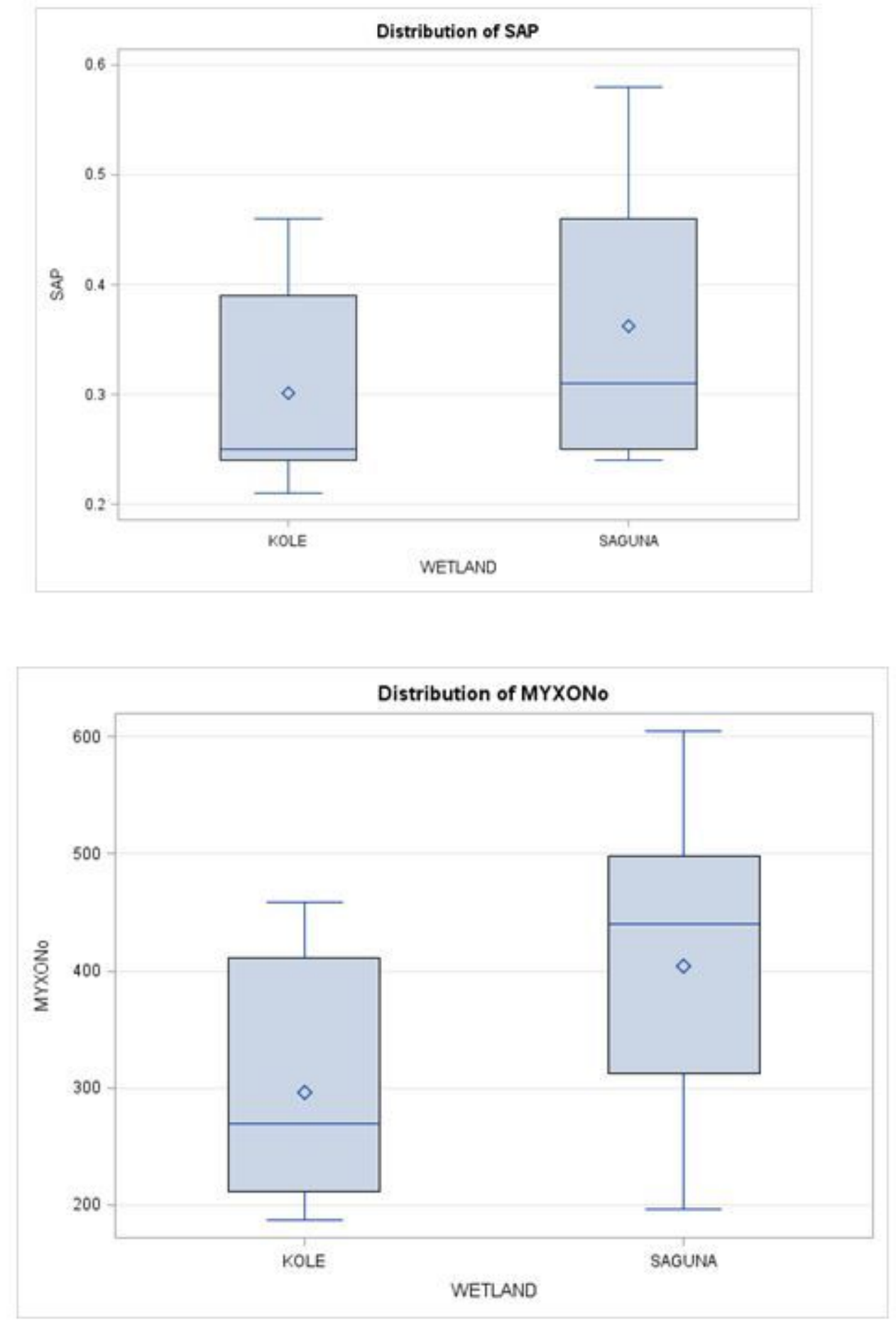

Figure 8

8a: Boxplot for available phosphorous of soil of the selected floodplain wetlands 8b: Boxplot for Myxophyceae of the selected floodplain wetlands 

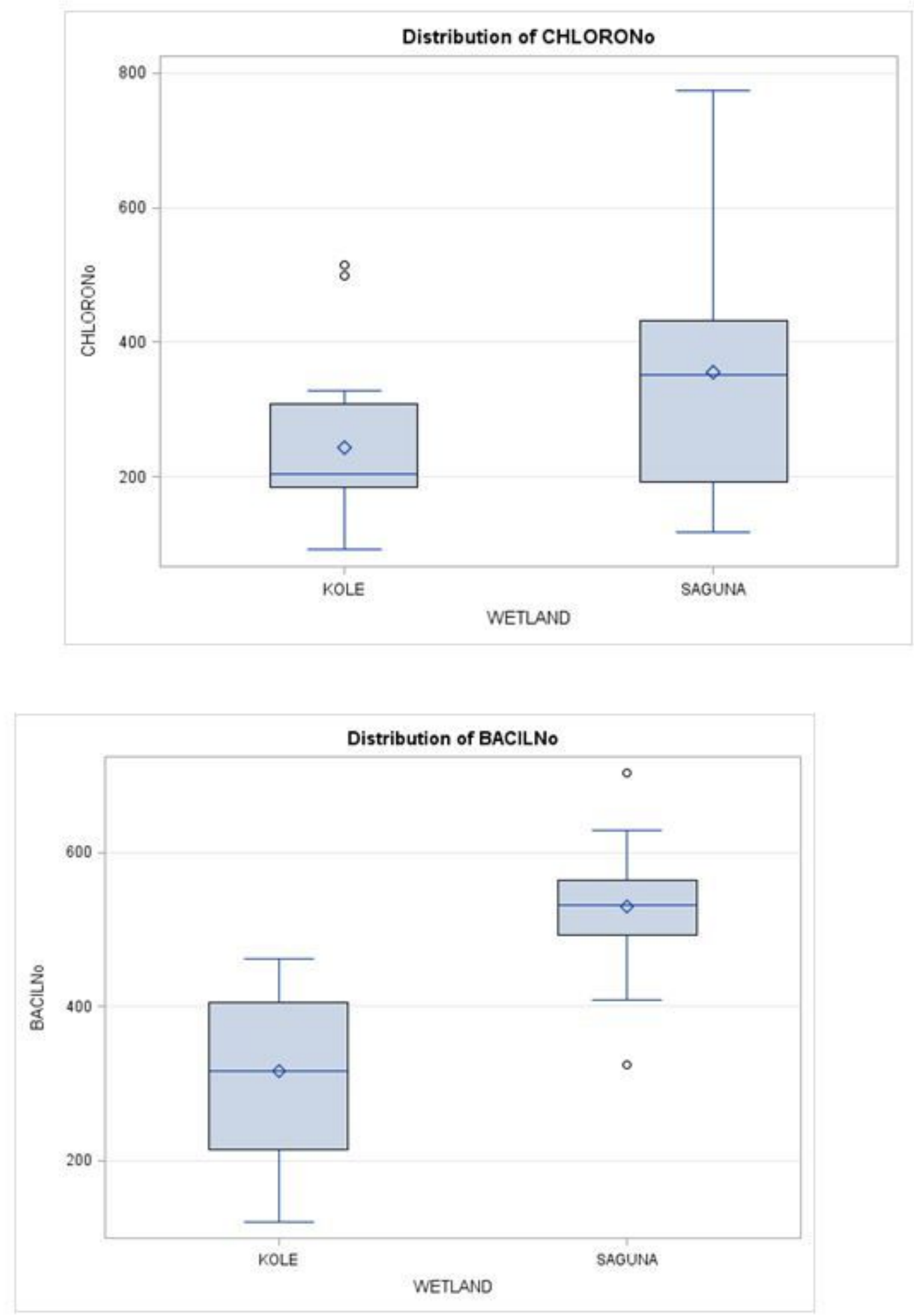

\section{Figure 9}

9a: Boxplot for Chlorophyceae of the selected floodplain wetlands 9b: Boxplot for Bacillariophyceae of the selected floodplain wetlands 

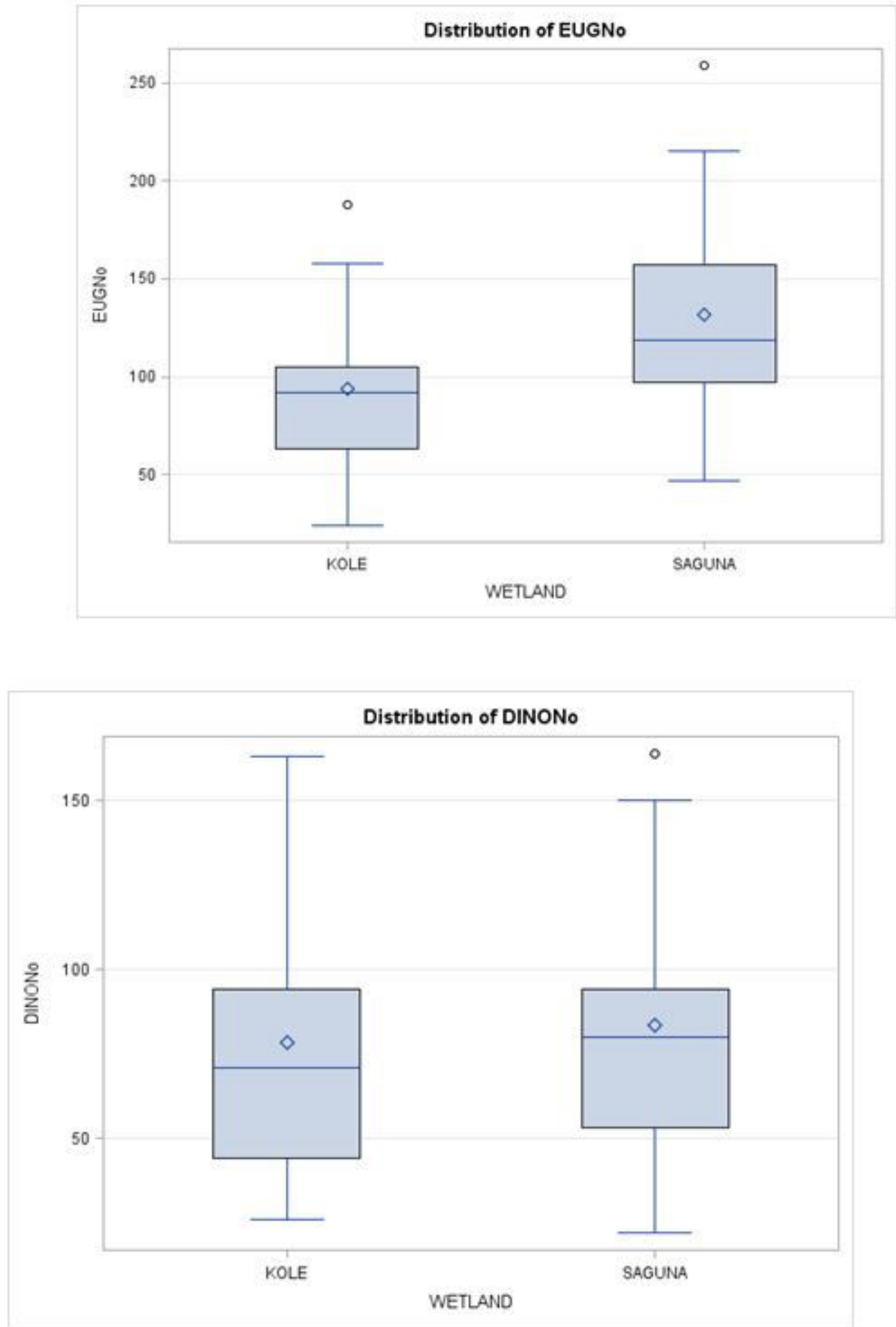

Figure 10

10a: Boxplot for Euglenoida of the selected floodplain wetlands 10b: Boxplot for Dinophyceae of the selected floodplain wetlands 


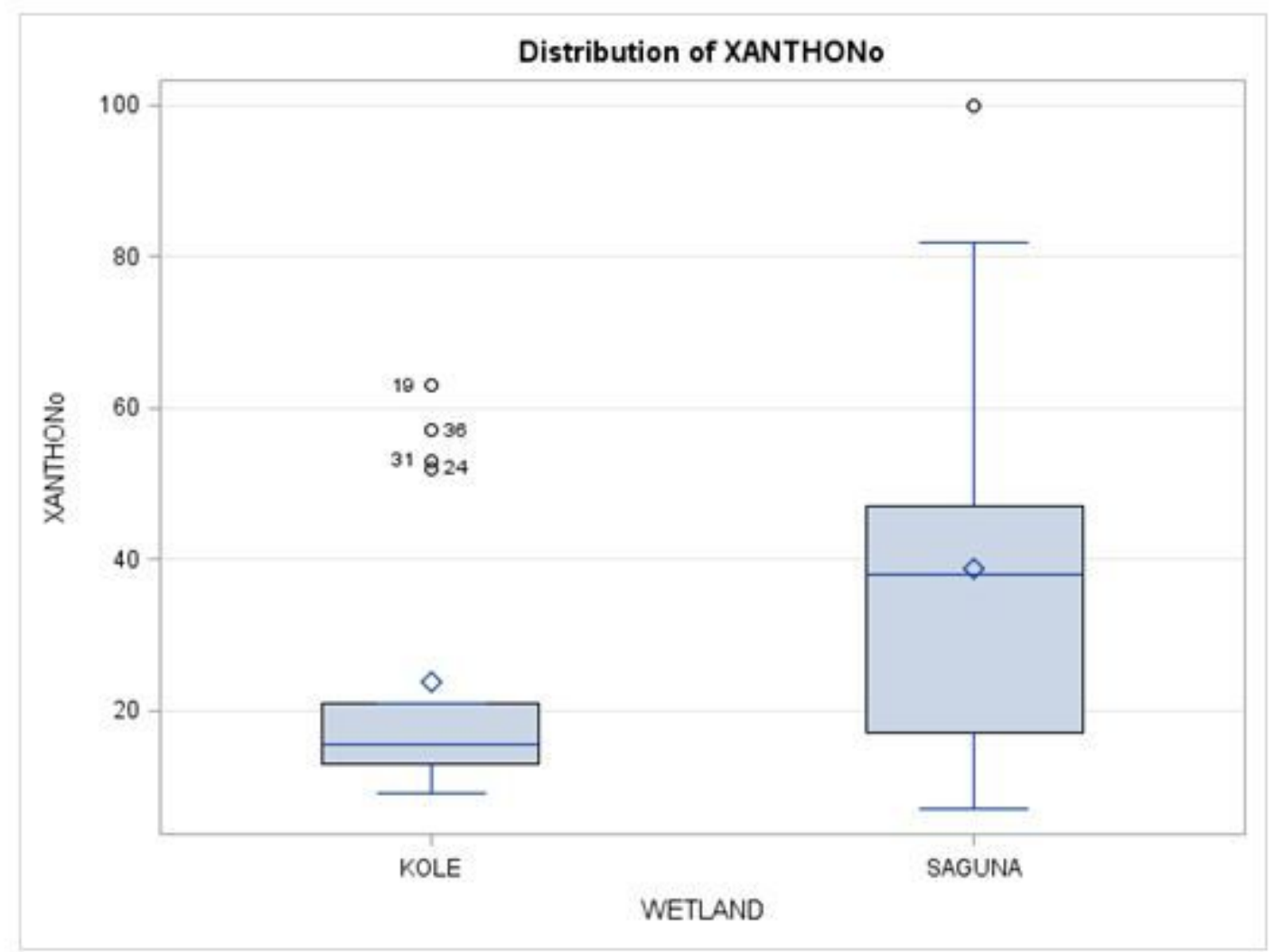

Figure 11

11a: Boxplot for Xanthophyceae of the selected floodplain wetlands 

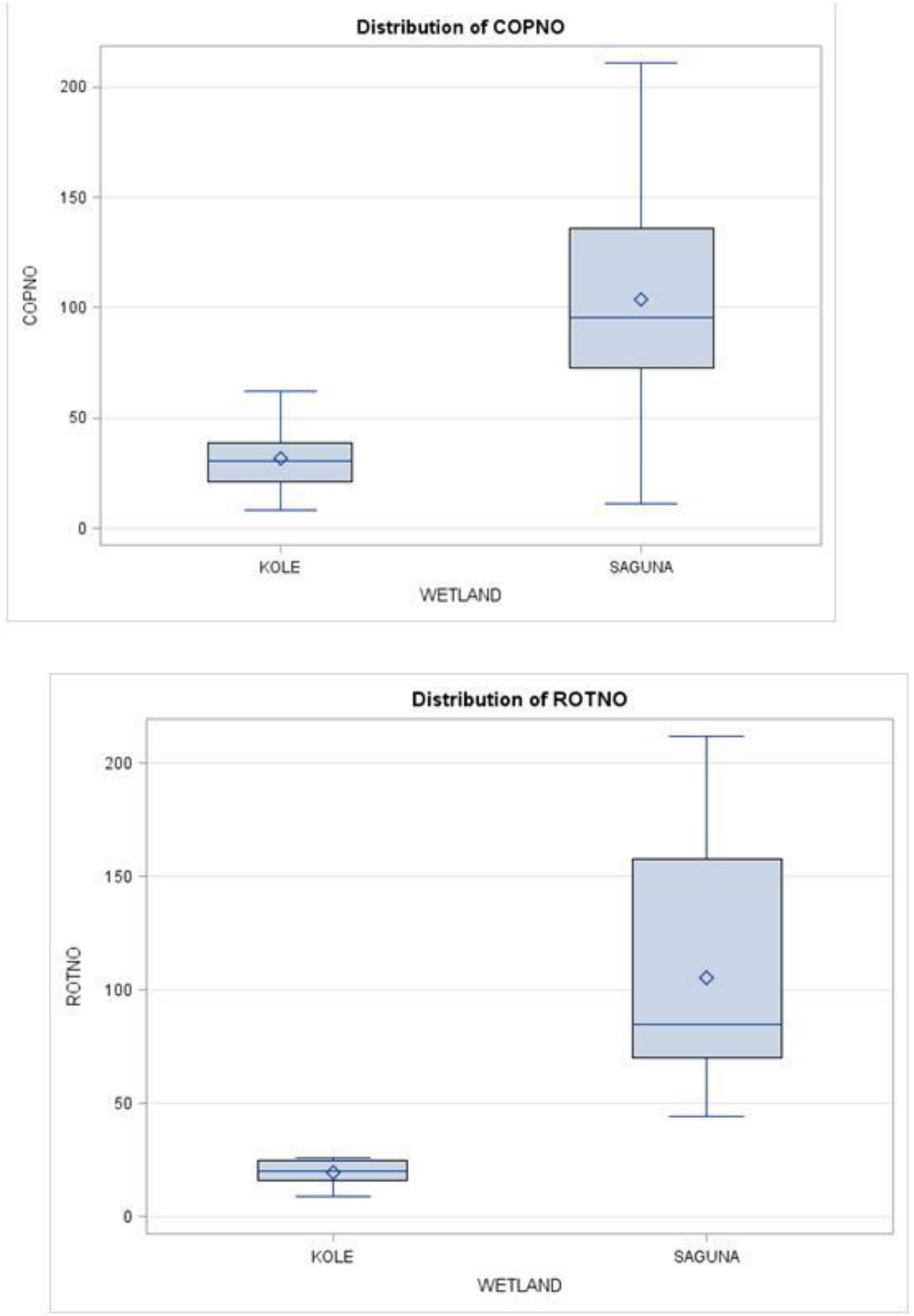

Figure 12

12a: Boxplot for copepoda of the selected floodplain wetlands 12b: Boxplot for Rotifers in the selected floodplain wetlands 

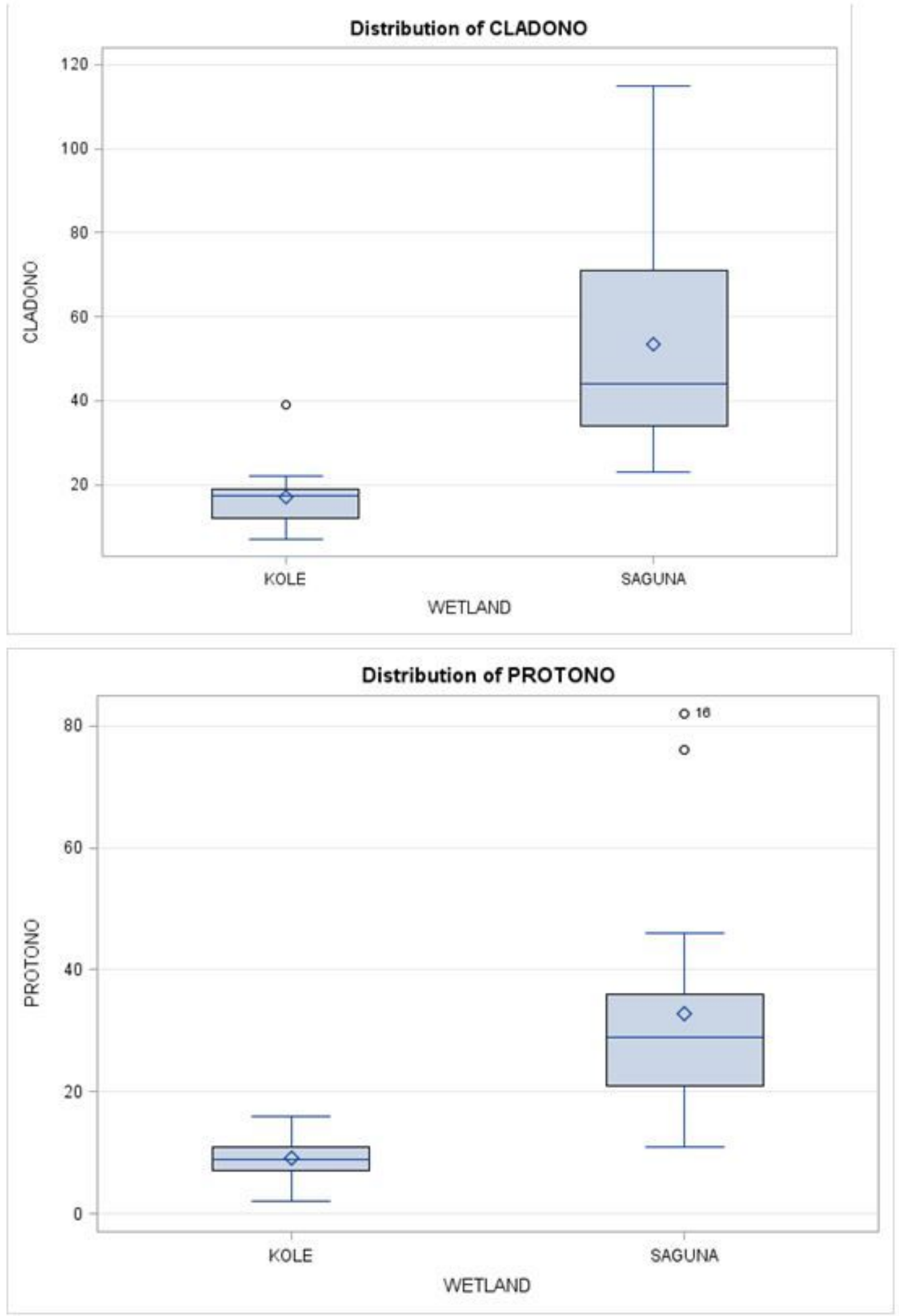

Figure 13

13a: Boxplot for Cladoceron of the selected floodplain wetlands 13b: Boxplot for protozoa of the selected floodplain wetlands 

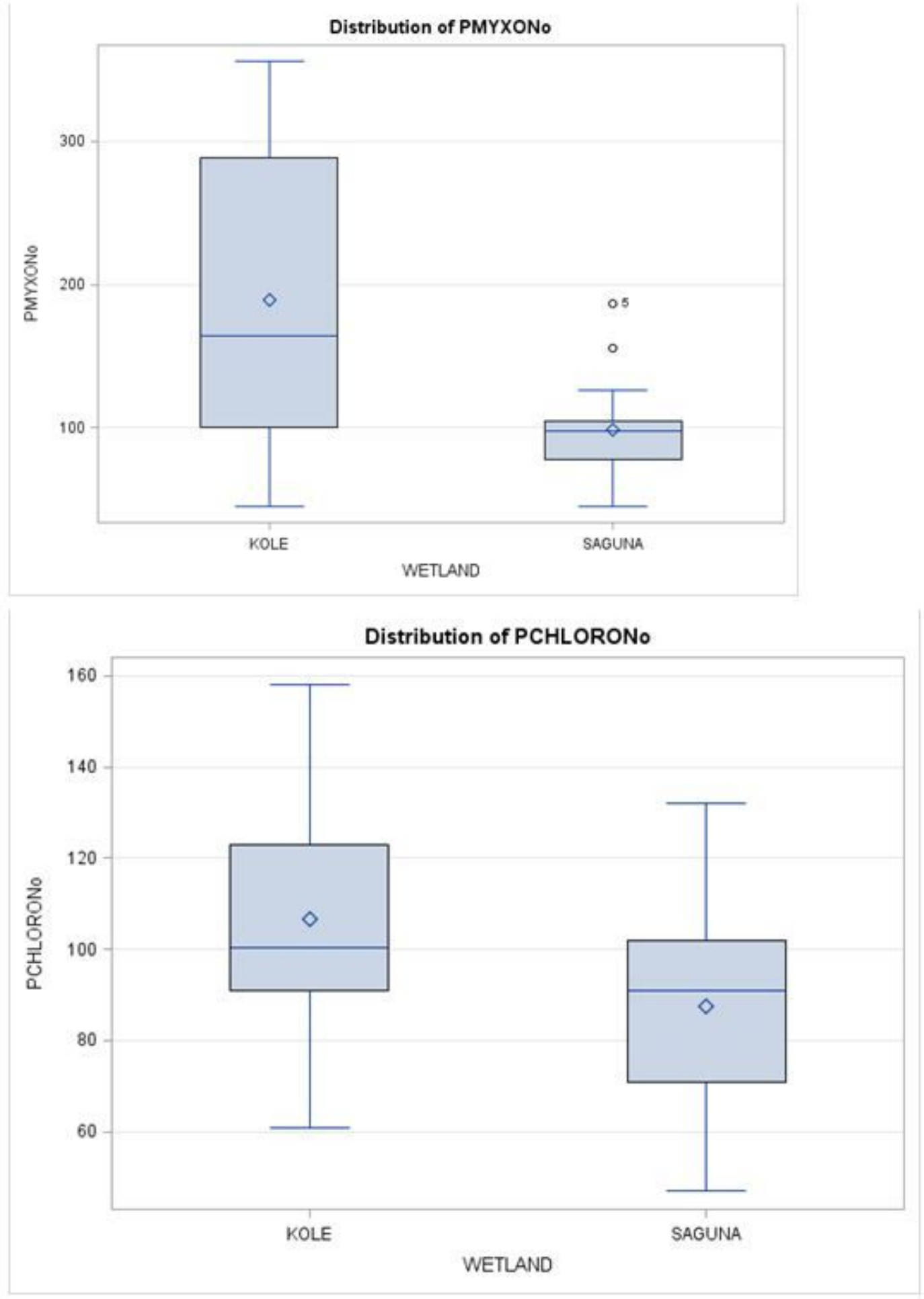

Figure 14

14a: Boxplot for Myxophyceae (Periphyton) of the selected floodplain wetlands 14b: Boxplot for Chlorophyceae (Periphyton) of the selected floodplain wetlands 

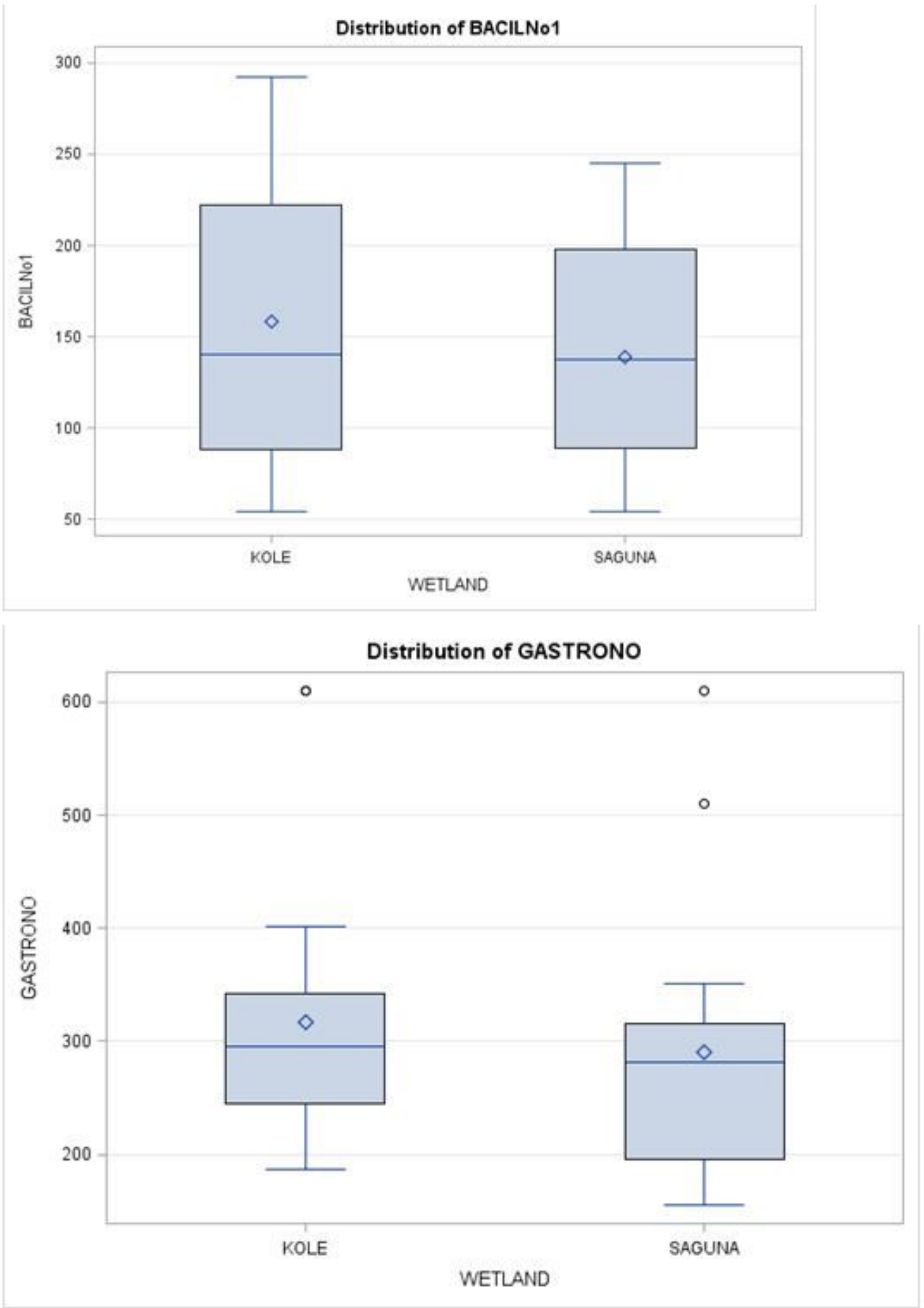

\section{Figure 15}

15a: Boxplot for Bacillariophyceae (Periphyton) of the selected floodplain wetlands 15b: Boxplot for Gastropod of the selected floodplain wetlands 

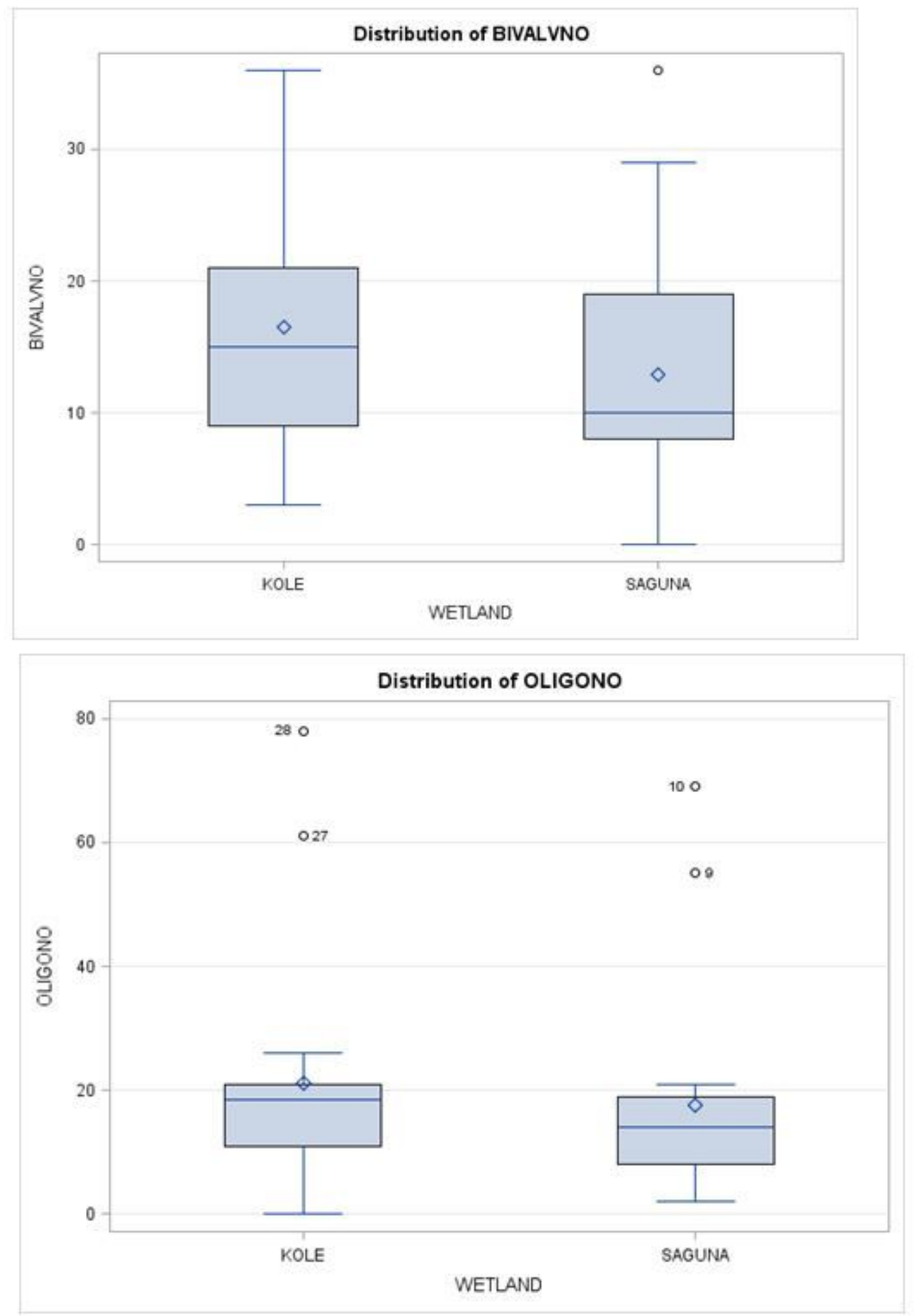

\section{Figure 16}

16ac: Boxplot for Bivalve of the selected floodplain wetlands 16b: Boxplot for Oligochaete (Benthos) of the selected floodplain wetlands 

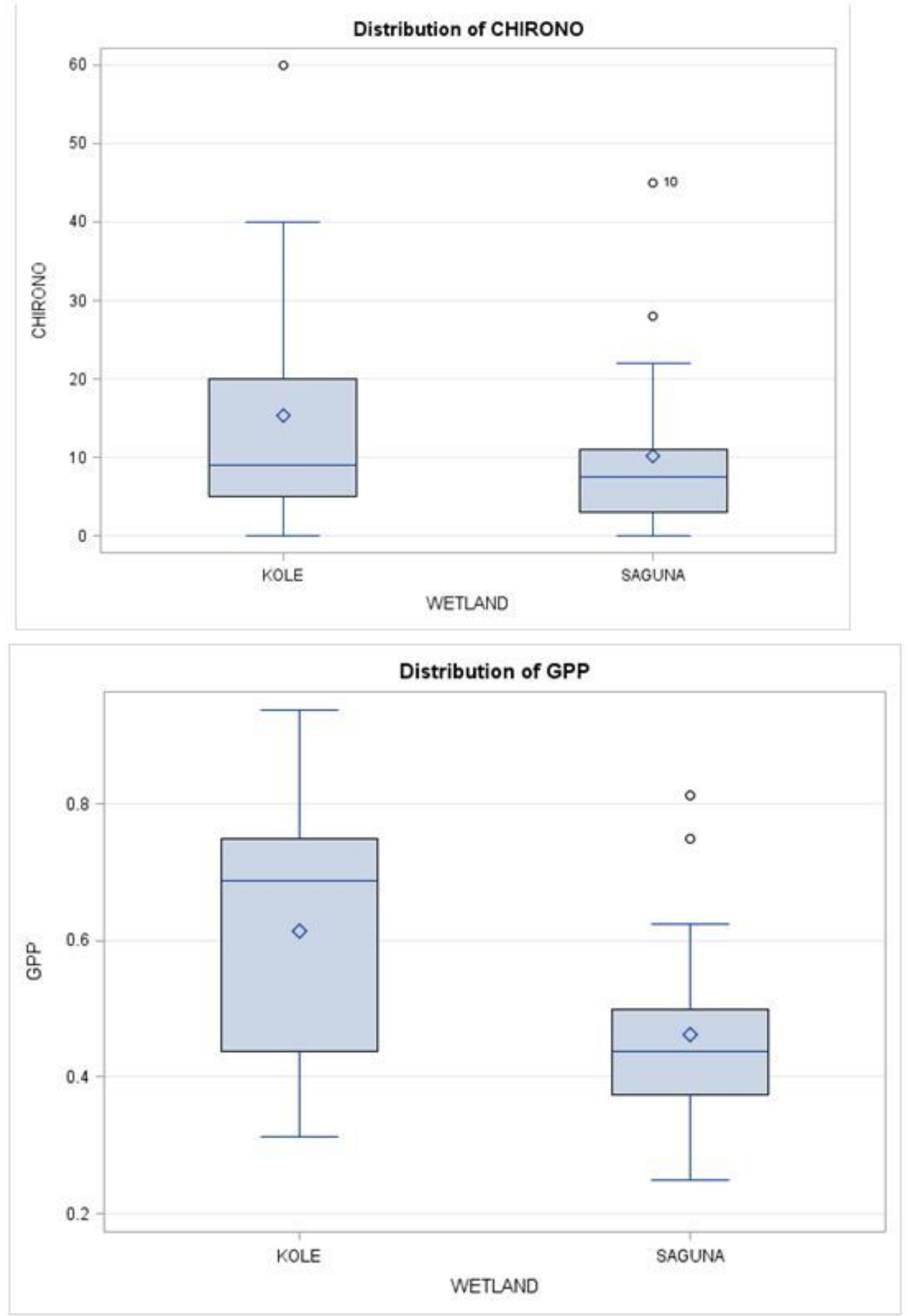

Figure 17

17a: Boxplot for Chironomids (Benthos) of the selected floodplain wetlands 17b: Boxplot for Gross Primary Productivity of the selected floodplain wetlands 

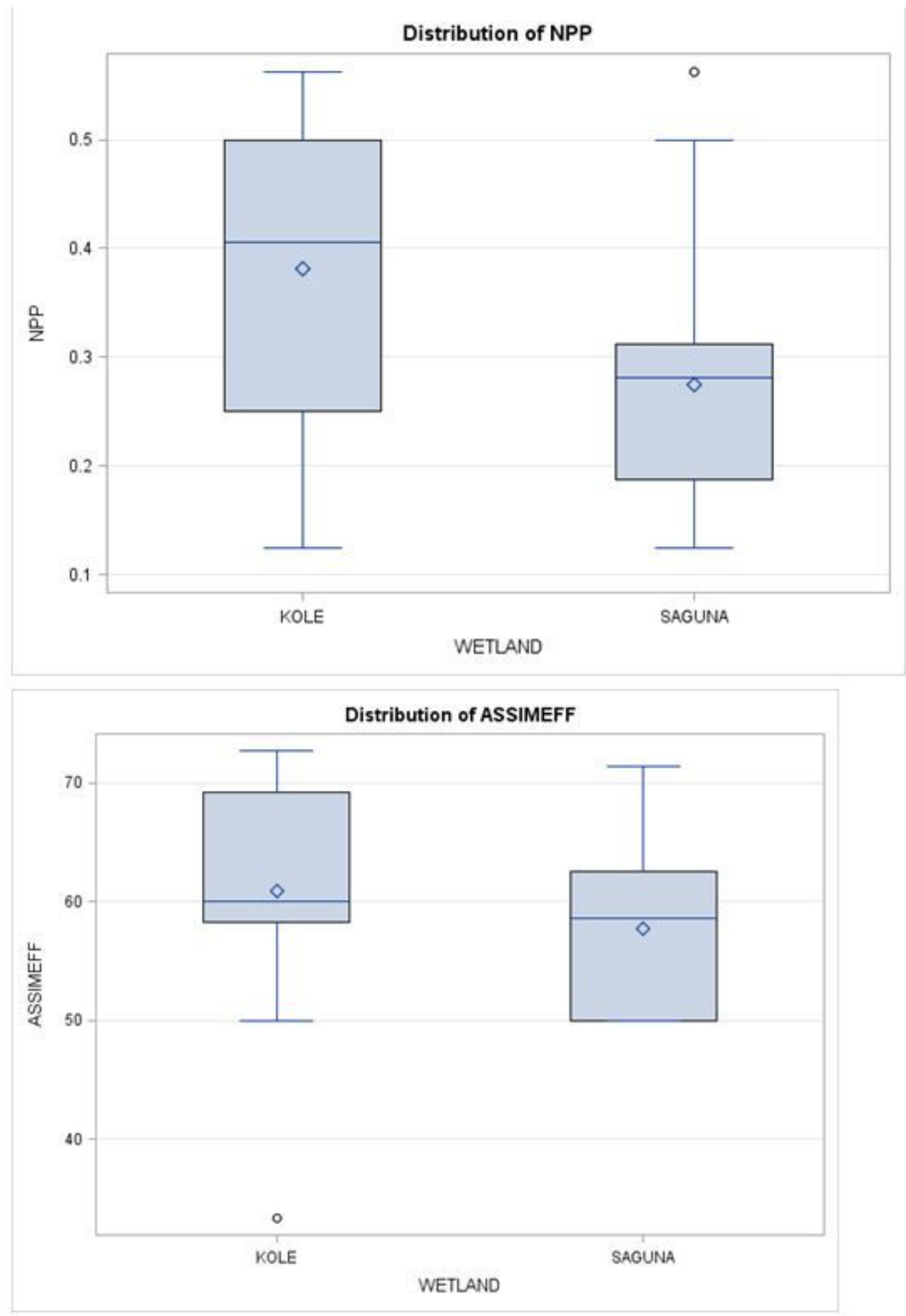

\section{Figure 18}

19a: Boxplot for NPP of the selected floodplain wetlands 19b: Boxplot for Assimilaion efficiency of the selected floodplain wetlands 

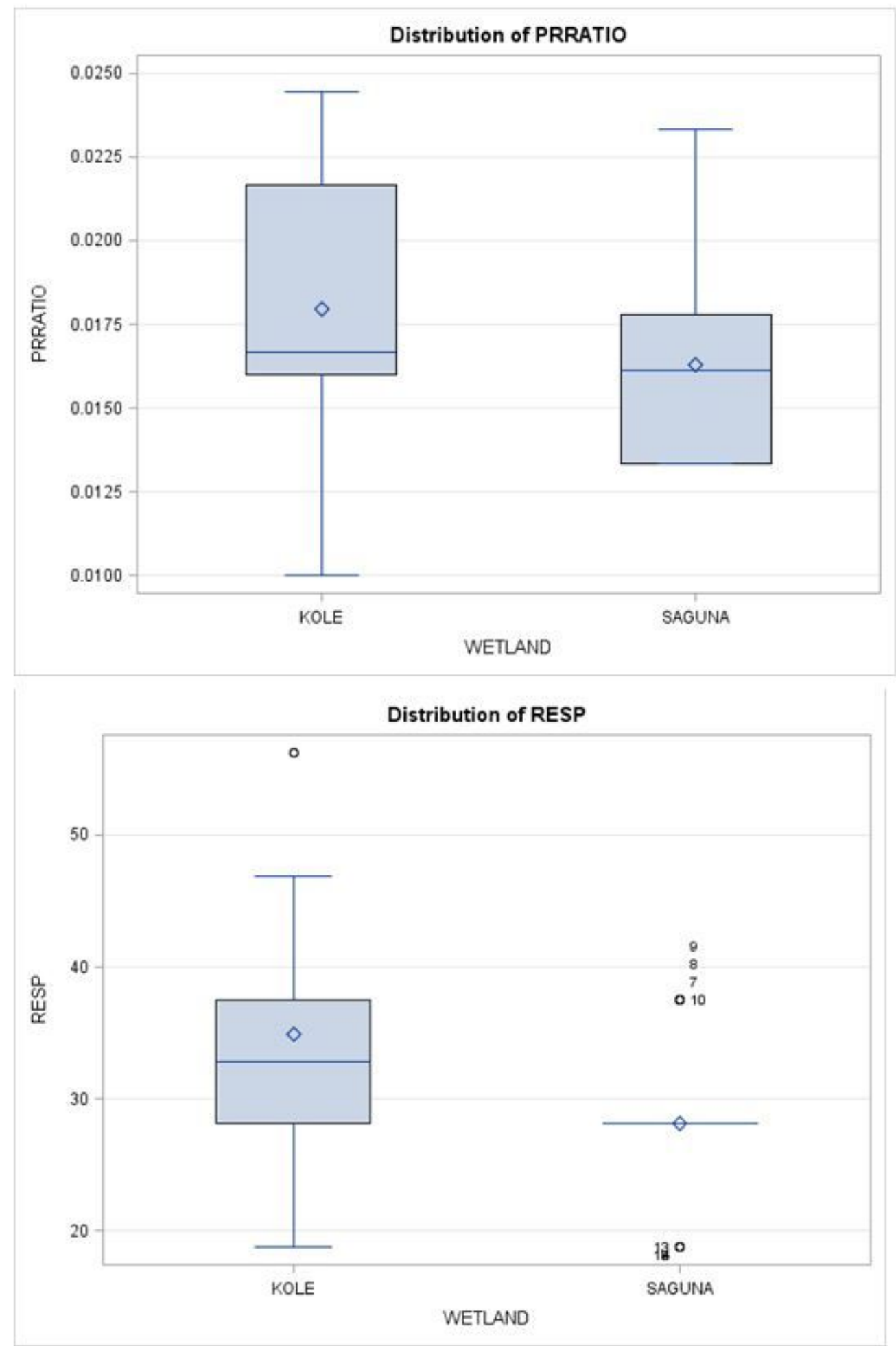

Figure 19

20a: Boxplot for prratio of the selected floodplain wetlands 20b: Boxplot for respiration of the selected floodplain wetlands 